(1) AFRICAN ECONOMIC

RESEARCH CONSORTIUM

(A) $A E R C$ research papors

RP 169

AUG. 2007

\title{
A MODELLING OF GHANA'S INFLATION EXPERIENCE: 1960-2003
}

Mathew Kofi Ocran

AFRICAN ECONOMIC RESEARCH CONSORTIUM

CONSORTIUM POUR LA RECHERCHE ECONOMIQUE EN AFRIQUE 
Rn 281800

\title{
LIERARY
}

2 2 IUL 200C

\section{A Modelling of Ghana's Inflation Experience: 1960-2003}

By

\author{
Mathew Kofi Ocran \\ Ghana Institute of Management \\ and Public Administration \\ Accra, Ghana
}

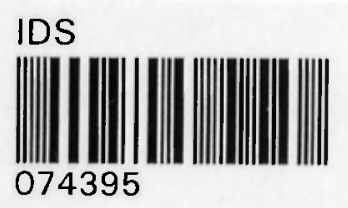

AERC Research Paper 169

African Economic Research Consortium, Nairobi

August 2007 
THIS RESEARCH STUDY was supported by a grant from the African Economic Rescarch Consortium. The findings, opinions and recommendations are those of the author, however, and do not necessarily reflect the views of the Consortium, its individual members or the AERC Secretariat.

Published by: The Alrican Economic Research Consortium P.O. Box 62882 - City Square Nairobi 00200, Kenya

Printed by: Modern Lithographic (K) Ltd P.O. Box 52810 - City Square Nairobi 00200, Kenya

ISBN $\quad 9966-778-14-4$

(1) 2007, African Economic Research Consortium. 


\section{Contents}

List of tables

List of figures

Abstract

Acknowledgements

I Introduction

2 Ghana's inflation experience: Some stylized facts 5

3 Methodology 17

4 Conclusions $\quad 27$

$\begin{array}{ll}\text { Notes } & 29\end{array}$

$\begin{array}{ll}\text { References } & 30\end{array}$

Appendix: Results of unit root and other tests 32 


\section{List of tables}

1. Comparison of weights in the consumer price index, 1977 and $1997 \quad 5$

2. Episodes of persistent moderate inflation since $1960 \quad 10$

3. Economic orientation of successive governments in Ghana, 1960-2003 15

4. Descriptive statistics for selected macroeconomic variables 16

5. Monetary sector: Johansen eigenvalues and associated test statistics 21

6. Monetary sector VAR (non-normalized) 22

7. Monetary sector VAR with normalization on money 22

8. External sector: Johansen eigenvalues and associated test statistics 23

9. External sector VAR normalized on $p-e-q$

10. Monetary sector: Tests for weak exogeneity 24

11. External sector: Tests for weak exogeneity 25

12. Parsimonious error correction model, 1961.2 to 2003.4

A I.Unit root test for data series $\quad 32$

A2. Tests of significance of each variable: Monetary sector VAR 32

A3.Test of significance of all lags up to 4: Monetary sector VAR 33

\section{List of figures}

1. Trends in CPI inflation, 1960-2003 7

2. Trends in output growth and inflation, 1960-2002 11

3. Trends in inflation and money and quasi-money growth, 1960-2002 12

4. Trends in nominal exchange rate depreciation, 1960-2003 13

5. Annual average nominal interest rates and inflation, 1960-2003 13

6. Fiscal deficits and inflation, 1960-2003 14 


\section{Abstract}

The study sought to ascertain the key determinants of inflation in Ghana for the past 40 years. Stylized facts about Ghana's inflation experience indicate that since the country's exit from the West African Currency Board soon after independence, inflation management has been ineffective despite two decades of vigorous reforms. Using the Johansen cointegration test and an error correction model, the paper identified inflation inertia, changes in money and changes in Government of Ghana treasury bill rates, as well as changes in the exchange rate, as determinants of inflation in the short run. Of these, inflation inertia is the dominant determinant of inflation in Ghana. It is therefore suggested that to make treasury bill rates more effective as a nominal anchor, inflationary expectations ought to be reduced considerably. 


\section{Acknowledgements}

Financial and institutional support, respectively, from the African Economic Research Consortium (AERC) and the Ghana Institute of Management and Public Administration (GIMPA) for this paper is gratefully acknowledged. Helpful comments from the resource persons and other workshop participants in AERC's Thematic Group B are also appreciated. The views expressed in the paper are those of the author, however, and not of AERC or GIMPA. 


\section{Introduction}

$\mathrm{G}$ hana's inflation experience since independence has been difficult. The tïrst five years after independence, 1957-1962, saw relative stability in price determination as inflation hovered around a single digit. The 1970s and early 1980s, on the other hand, recorded unprecedented macroeconomic instability and very high inflation episodes. Indeed inflation exceeded $100 \%$ on four occasions between July 1977 and March 1983. Ghana embarked on a stabilization policy supported by the Bretton Woods Institutions in 1983, but the stabilization appeared to have done very little to resolve the persistent high and variable inflation. Over the past 35 years, the country has not had an occasion of single-digit inflation; indeed, it has recorded annual average inflation rates in excess of $25 \%$ in more than half of those years. Sowa (1994) among others asserts that inflation has been an albatross of the economic reform programme for which no remedy has worked, and ten years on an antidote is yet to be found. A conference' on Ghana involving civil society, government, political parties and other stakeholder representatives agreed that Ghana suffers from a chronic inflation problem. Additionally, in a recent study by Catoa and Terrones (2003), Ghana was cited as one of the top 25 countries in the world with high inflation levels.

The question that comes to mind after considering these issues concerns factors that adequately explain inflation in Ghana. Relatedly, is there an economically interpretable long-run relationship among general prices, output, interest rate, money and the exchange rate? And lastly, how has the impact of inflation unfolded over the years? The primary concern of the present research effort is to model inflation processes in Ghana. The specific objectives are to build an econometric model that adequately explains inflation in Ghana; to identify the relative importance of these factors; and to ascertain the presence or otherwise of an economically interpretable long-run relationship between general prices, output, interest rate, money and exchange rate.

Different views both empirical and theoretical have emerged in the literature as far as the modelling of inflation is concerned. The monetary approach stresses the relationship that exists between money supply and prices. Monetarists therefore argue for policies that aim at curbing money supply whether domestic or foreign. The second approach analyses structural and cost-push factors. The structuralist dwells on structural factors such as whether the market works and cost-related pressures including import prices. Yet another group emphasize that monetary expansion occurs in response to misalignment or imbalances and that monetary expansion is itself a reflection of other elemental causes such as fiscal imbalances; this constitutes the public finance approach and is essentially a variant of the structuralist. Debate about the causes of inflation in the literature is therefore generally between the monetarist and the structuralist. 
Following Harberger's (1963) seminal work on price determination in Chile, the monetarist model formed the theoretical framework of many empirical analysis of inflation in developing countries (see Bhalla, 1981; Sani, 1982). Edgen et al. (1969) and Parkin (1977) affirmed that the monetary model was unworkable as a representation of small open economies with fixed exchange rate regimes. In order to render the monetarist model more realistic and workable, certain adjustments such as the incorporation of cost-push factors to make the model more consistent with the purchasing power parity (PPP) approach have been recommended. Harberger and others have made changes in the standard monetary approach to account for financial repression and underdeveloped financial markets using past inflation rate as a proxy of the cost of holding cash. Sani (1982) also introduces the growth rate of import prices into the model. An adjustment of the standard monetary model is also effected with the inclusion of import price and the relative price of food to account for food supply shocks. Bhalla's 1981 paper applied the basic and adjusted monetary models to 29 developing countries for the period 1956 1975; a real activity model was also applied in the explanation of inflation via aggregate demand and price expectations. The basic monetarist model outperformed the real activity model; nonetheless, the adjusted monetary model performed best.

Chhibber (1992) applied a model that was a fusion of the monetarist and cost-push features to a small number of African economies. In the study inflation was given as a weighted average of inflation for traded goods, non-traded goods and controlled price goods. The resulting Chhibber model was found to be more general and involving than the one espoused by Bhalla (1981) and Sani (1982). One other interesting study aimed at explaining inflation is that by Lim and Papi (1997). This paper analysed price determination within the broad construction of a multi-sector macroeconomic model. The paper assumed the economy was represented by four sectors - goods, money, external markets and labour markets. Whereas long-run price formation was thought to be determined by the equilibrium in the goods market, the short-run dynamic model of inflation was made of the core long-run price model adjusted for the market disequilibrium tcrms in the other three. The study revealed that even though the monetary variable played an important role in determining inflation in Turkey, public sector deficit and inertial factors were equally quantitatively important in explaining the inflation processes.

The literature on inflation in Ghana is limited. The few available papers were mostly conducted during the economic reforms of the early 1980s and 1990s. Nonetheless, the limited amount of work can still be catalogued on the basis of the monetarist and structuralist paradigms. Bawumia and Atta-Mensah (2003), using a vector error correction forecasting (VECF) model, conclude that inflation was a monetary phenomenon in Ghana. Their paper does not explore the potential for real factors in price determination. Dordunoo (1994) observes that rapid exchange rate depreciation and resultant hikes in import prices were in themselves inflationary. In contrast, a school of thought championed by Chhibber and Shaffik (1991) holds the view that since most prices with the exception of petroleum prices were transacted at the parallel exchange rate. depreciation of the official exchange rate could not have affected inflation significantly.

Chhibber and Shaffik (1991) demonstrated that devaluation was indeed antiinflationary. Their study used three transmission mechanisms, fiscal/monetary, costpush factors and other real factors. These were represented in a single framework. 
Drawing on the defined framework. and using the Walrasian approach. they generated a model of inflation process consisting of wage-push, exchange rate related costs and their accompanying markups over costs. The markup was made a function of excess money supply. Thus an all-encompassing model of exchange rate, monetary and fiscal factors as well as real factors as explanatory variables was estimated. Among other things. the paper pointed out that inflation in Ghana was mostly a monetary phenomenon. The presence of real factors in the model by way of monetary factors (a la Walras) may probably have reduced the full effect of the real factors and possibly led to an overestimation of the real monetary effect in the price determination. Sowa and Kwakye (1991) support this assertion.

Those of the structuralist school have critiqued the monetarist explanation of the persistently high and variable inflation particularly during the years of the economic reforms (Sowa and Kwakye, 1991; Sow'a, 1994; CEPA. 1996). The structuralists argue that real factors that constitute supply-side constraints explain Ghana's inflationary experience better than any other factors. The thrust of Sowa and Kwakye's attempt at explaining the country's inflationary experience for the period 1963-1989 fails to compare the pre- and post-reform periods, yet that was stated as one of the objectives of the study. These authors had in their inflation equation regressors such as money, output exchange rate and price expectations, but their model did not capture the short-run dynamics inherent in the inflation process. Nevertheless, the study concluded that inflation in Ghana was due to both real and monetary shocks. It also acknowledged the dominance of supply-side factors in explaining inflation in the Economic Recovery Programme (ERP) era. The authors concluded that output pressures on the economy far outweighed monetary pressures. Contrary to the position taken by Chhibber and Shaffik (1991), Sowa and Kwakye maintained that exchange rate devaluation had a positive effect on inflation as underscored by a later study by Durdonoo (1994). On the weaknesses of the paper, one would have expected that structural differences between the pre-ERP and ERP period would be ascertained so as to throw light on whether there was any structural shift in the inflation determinants over the two periods.

Sowa $(1994,1996)$ also estimated an inflation equation for Ghana using data spanning the years 1963 to 1990, thus covering the period of economic deterioration and economic reforms. Carried out with the aid of an error correction model, unlike Sowa and Kwakye (1991) and other earlier studies, Sowa brought to the fore some short-run dynamics that were missing from previous studies on inflation in Ghana. However, in the long-run specification of the model for price determination, he dropped interest rate as an independent variable, arguing that in other studies (such as Adam et al., 1996) it had been found to be statistically insignificant as an explanatory variable.

Yet, the importance of the level of inflation rate as a macrocconomic indicator cannot be overemphasized. Adequate knowledge of the factors that determine inflation in any given economy is crucial if exchange rate, monetary and fiscal policies are to be effectual in controlling inflation (Atta et al., 1996). Unfortunately, the management of inflation in Ghana over the years, especially since the early 1970s, has been ineffective. High inflation has rendered the cost of loanable funds prohibitive. Subsequent high interest rates have in turn prevented productive sectors of the economy from accessing finance for growth and development (FIAS, 2002). 
The present study covers a span of time during which a number of economic policies were pursued, including those under the aegis of the World Bank and International Monetary Fund (IMF) economic reform programmes. There have also been a number of internal and external shocks that together had a negative impact on inflation. The few available studies on inflation in Ghana were conducted in the early to middle $1990 \mathrm{~s}$ (Sowa, 1996, 1994; Sowa and Kwakye, 1991; Chhibber and Shaffik, 1991). Recent studies relating to inflation in Ghana have been mostly part of multi-country efforts and have thus been broad strokes and less focused (see Catoa and Terrones, 2003; Loungani and Swagel, 2001; Braumann, 2000).

The rest of the paper is structured as follows: the second section reviews some of the stylized facts about inflation in Ghana over the period 1960-2003. Section Three presents a discussion of the methodology adopted for the empirical analysis, followed by the results of the empirical analysis in Section Four. The last section considers the conclusions and policy implications of the study. 


\title{
2. Ghana's inflation experience: Some stylized facts
}

\begin{abstract}
A good appreciation of the inflationary experience in Ghana during a period in which the country witnessed both volatile and stable growth certainly requires 1 an assessment of the proximate causes of the phenomenon. The discussion here begins with a descriptive analysis of the structure and composition of consumer price index (CPI) baskets for the past 30 years. This section of the paper also attempts to assess trends in the relevant monetary and fiscal policy variables over the period 19602003. We dwell on the movements in inflation, on the one hand, and monetary growth, exchange rate depreciation and fiscal deficit, on the other. The other variables whose trends are presented are interest rate and GDP growth. Finally, the section discusses the possible role of political business cycles in the inflation processes in Ghana and attempts to proffer reasons for any relationship with select key fiscal and monetary variables in Ghana over the study period.
\end{abstract}

\section{Structure and composition of consumer price index}

$\mathrm{O}$ ver the last 30 years the composition and structure of the basket of goods and services that determines inflation has seen some marked changes. The apparent dominance of the weight of food and beverage prices in the CPI basket has remained largely unchanged (see Table l). This situation lends credence to the key role of agriculture in price formation in the country. Historically, good harvests have tended to dampen inflationary pressures and vice versa.

Table 1: Comparison of weights in the consumer price index, 1977 and 1997

\begin{tabular}{lrrr}
\hline Commodity & $\mathbf{1 9 9 7 = 1 0 0}$ & $\mathbf{1 9 7 7 = 1 0 0}$ & $\begin{array}{c}\text { Change } \\
\text { in weight }\end{array}$ \\
\hline Food and beverages & 51.9 & 49.2 & $5 \%$ \\
Alcohol and tobacco & 3.6 & 6.2 & $-42 \%$ \\
Clothing and footwear & 9.6 & 19.2 & $-50 \%$ \\
Housing and utilities & 9.2 & 6.8 & $35 \%$ \\
Household goods, operations and services & 7.3 & 5.1 & $43 \%$ \\
Medical care and health expenses & 4.3 & 1.8 & $139 \%$ \\
Transport and communications & 6.5 & 4.3 & $51 \%$ \\
Recreation, entertainment, education and cultural services & 4.9 & 5.5 & $-11 \%$ \\
Miscellaneous & 2.7 & 1.9 & $42 \%$ \\
Combined & 100.0 & 100.0 & \\
\hline
\end{tabular}

Source: Ghana Statistical Service (GSS) data files, Accra. 
As suggested by the table, the importance of food prices has not reduced at all; if anything it has rather increased in importance albeit marginally (from $49.2 \%$ in the $1970 \mathrm{~s}$ to $51.9 \%$ in the $1990 \mathrm{~s}$ and $2000 \mathrm{~s}$ ). An important structural change can be observed in costs of medical care and other health expenses, however, which recorded a $139 \%$ increase in weight. Escalation in health cost in the basket can be attributed to the pay as you go system of health care financing that emphasized full cost recovery at the point of service.

Another important structural shift occurred in transport and communication (51\%); changes in the weight of this component of the CPI are an indication of the significance that fuel price is assuming in the inflation process. Also noteworthy is clothing and footwear, where the weight reduced from a high of $19.2 \%$ in the 1970 s to less than $10 \%$ in the 1990s (Table 1). Probably the massive influx of second-hand clothing, which appears to be cheap, may have reduced the budget on clothing; the side effect, however, has been the collapse of the textile industry.

\section{Evolution of Ghana's episodic inflation experiences, 1960-2003}

$I^{\mathrm{n}}$ nflation experience in Ghana from independence to 2003 can be characterized as episodic. Indeed, four distinct episodes can be isolated: the immediate postindependence period, which was up to 1966; immediate post-Nkrumah (1966-1972); the deterioration phase (1972-1982); and the most recent period (1982-2003), which we have termed the stabilization inflationary experience.

The first inflation episode began shortly after the exit of the country from the West African Currency Board (WACB) and lasted until the overthrow of the Nkrumah administration in February 1966. The period preceding the episode was tranquil as far as inflation developments were concerned because of the existence of the currency board, which had been established' in ' '91'2. The board' issued its first notes and' coins in '1946 and these remained legal tender in the four British colonies of West Africa (Ghana, Nigeria, Sierra Leone and The Gambia) until 1957 when Ghana opted out. By construct, the currency board had no control of discretionary monetary policy and as a result market forees determined money supply in Ghana and the other three countries. Consequently, the (ihanaian government financed its spending solely by taxing or borrowing and not by printing of money to fuel inflation.

Upon attainment of self-rule in 1957, the Nkrumah administration embarked on a massive industrialization drive unprecedented in the history of the country. Very high investment in infrastructure and the creation of import substitution industries on a large scale across the length and breadth of the country in no small measure contributed to the healing-up of the economy. The objective was to catapult the Ghanaian economy into the rank of the modern world in the shortest possible time. Alongside the industrial expansion was the institution of a far-reaching social welfare benefit system. This included free and ofien greatly subsidized social services (i.e., education, health and housing). The heavy puthic investment coupled with expenditure on social services was based on the likelihood of the continuation of the post-war boom in commodity prices and the sustained heary taxation of the cocoa crop. Even when the commodity market collapsed 
and the accumulated surpluses were eroded, the high investment thrust was maintained. but bankrolled with deficit financing and loans from overseas. Nkrumah's expansionary fiscal and monetary policies were possible because the stricture offered by the erstwhile West African Currency Board was no longer in place. During the currency board years inflation was in single digits. Indeed, in the currency board years inflation rates were typically estimated at less than $1 \%$. Between 1960 and 1963 , however. inflation averaged $8 \%$ per annum, then more than doubled to 23\% per annum between 1964 and 1966.

The army overthrow of Nkrumah`s socialist administration in February 1966 marked the beginning of the immediate post-Nkrumah inflation episode. The National Liberation Council (NLC) government formed by the military entered into a standby arrangement ${ }^{2}$ with the IMF. As part of the macroeconomic stabilization programme the government embarked on efforts to cool dow'n the economy. Among the key measures was a drive to liberalize external trade, and tighten monetary and fiscal policies. Nkrumah's public investment programme was curtailed considerably. The new government withdrew from the hitherto extensive state engagement in the productive sectors of the economy. A notable pursuit of the period was the devaluation of the cedi by $30 \%$ against the US dollar and a massive retrenchment exercise in the public sector that saw $10 \%$ of the wage-labour force going home ${ }^{3}$ (Hutchful, 2002). The combined effect of the fiscal and monetary policies led to an 8\% dethation in 1967 (see Figure 1), the only deflation recorded in the recent economic history of the country. Between 1967 and 1969 inflation averaged $2.3 \%$ per annum. It is important to note, however, that the very low rates of inflation of the first stabilization episode rather considerably dampened economic growth.

Figure 1: Trends in CPI inflation, 1960-2003

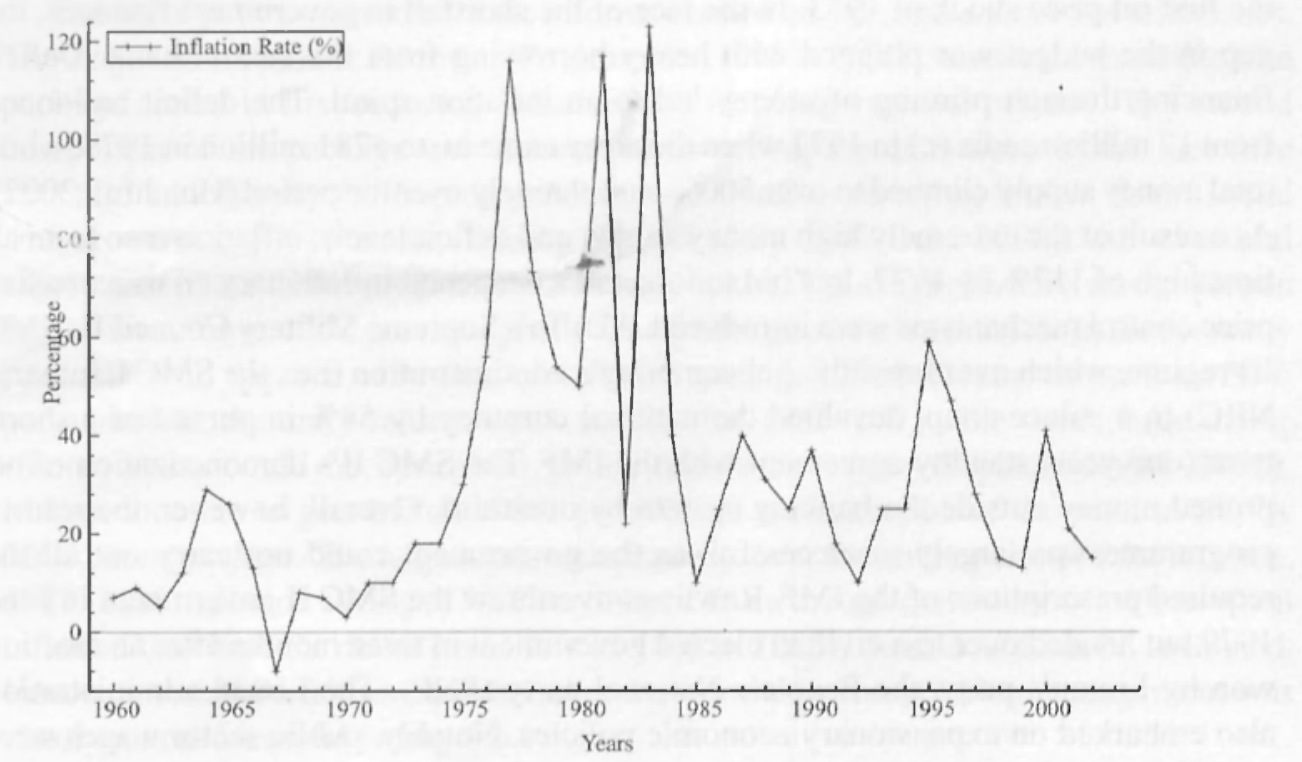

The civilian administration of the Progress Party (PP) government that succeeded the NLC further deepened the liberalization policies of the previous government but attempted to loosen the grip on fiscal policy. Drawing on the accumulated foreign reserves and loans contracted on the back of the goodwill enjoyed by the country, the PP 
government pursued an economic stimulation programme - albeit cautiously - by increasing capital and recurrent expenditures. The government also encouraged the private sector by playing a facilitating role. Inflation was still kept in check despite the relatively loose fiscal policies because monetary policy was still contractionary in orientation, but from a trough of $3 \%$ inflation surged to $10 \%$ in 1970 . Economic policies of the regime supported import supplies that in turn led to impressive output growth. Commodity prices tumbled in 1971, however, and the government went down with them. The subsequent Busia government's attempt to contain the economic impact of the commodity price collapse by putting together an austerity budget that sought to cut back on expenditures and also institute additional revenue measures became very unpopular. IMF prevailed on the government to devalue the currency by $44 \%$. Additionally, the government on its own levied an additional tax of $10-20 \%$ on some foreign exchange transactions the following month, thus creating a certain degree of devaluation. In January 1972 the government was kicked out by the military again.

When the National Redemption Council ${ }^{4}$ (NRC) led by Acheampong overthrew the Busia administration, economic policy direction was largely reversed. The cedi was first revalued by $42 \%$ and the controls on external trade were reinstated (ostensibly to reverse the devaluation by the previous administration).

The austere economic measures put in place by the Busia regime were eased. The development levy of $7 \%$ imposed by the previous administration was scrapped, whilst benefits and some allowances withdrawn from civil and public servants were restored. It is argued that the 1972-1978 period saw the most reckless expansionary economic policy stance ever in the history of the country. The balance of payments position, which had improved as a result of very high gold and cocoa prices in 1971/72, was eroded by the first oil price shock of 1973. In the face of the shortfall in government finances, the gap in the budget was plugged with heavy borrowing from the central bank. Deficit financing through printing of money led to an inflation spiral. The deficit ballooned from 17 million cedis $(\not)$ in 1971 when the army came in, to $\notin 781$ million in 1977, while total money supply climbed to over $500 \%$ cumulatively over the period (Hutchful, 2002). As a result of the extremely high money supply and deficit levels, inflation rose to an all time high of $117 \%$ by 1977 . In a bid to forestall a deepened inflationary crisis extensive price control mechanisms were introduced. Akuffo's Supreme Military Council II (SMC II) regime, which overthrew the Acheampong's administration (i.e., the SMC I, hitherto NRC) in a palace coup, devalued the national currency by $58 \%$ in pursuit of a shortterm (onc-year) standby agreement with the IMF. The SMC II's demonetization effort pruned money outside the binking system by one-third. Overall, however, the reform programme was largely unsuccessful, as the government could not carry out all the required prescriptions of the IMF. Rawlings overthrew the SMC II government in June 1979 but handed over to a civilian elected government in three months after an election won by Liman's party, the People's National party (PNP). The Liman administration also embarked on expansionary economic policies. Notably, public sector wages were tripled over night whilst the producer price for cocoa was also doubled. A wavering and incoherent policy stance of the regime did little to bring sanity to the economy. Rawlings came back in December 1981 in a second military coup, 27 months after the first one. 
In sum, the inflationary experience in most of the period 1972-1982 was largely due to expansionary fiscal and loose monetary policies. In addition to a weak production base and subsequent low output, the fortunes on the world commodities market also influenced the inflationary trend in quite significant ways as indicated earlier. One other important observation was the attempt at using controls (i.e., fixed exchange rate, import licensing, and administered prices for goods and services) to hold down inflation.

The fourth inflation episode was occasioned by a combination of unfavourable conditions both man-made and natural. The price distortions of the late 1970s and an almost dysfunctional economic system forced the second Rawlings administration to adopt an IMF and World Bank supported programme. By 1982, the deficit had been restrained and financed using non-inflationary measures; money supply growth. which averaged $64 \%$ in 1981, was brought down to $24 \%$ by 1982 . Other non-orthodox measures were pursued, including the seizure of 50-cedi notes and bank balances of $\phi 50,000$ or more pending investigations, as well as a relentless war against tax defaulters. Zeal to restore the health of the economy notwithstanding, the absence of a well thought out medium-term economic programme brought to naught efforts to kick-start the economy. The worse was yet to come in 1983. Nigeria cut off crude oil exports to Ghana and also expelled over 1 million illegal Ghanaian migrants. The rain failed and the ensuing drought engendered widespread bushfires that devastated both cocoa and food crop production, thereby pushing the country into famine. It was against this background of economic malaise that the IMF and World Bank programme was adopted in April 1983. The high inflation rate of $123 \%$ recorded in 1983 was due in part to the devaluation of the cedi by a whopping $991 \%$, from $\notin 2.75$ to $\notin 30$ to the US dollar.

The set of policy measures for the reforms centred on three main phases or milestones. The stage one Economic Recovery Programme I (1983-1986) constituted a stabilization package aimed at first reducing inflation and fostering external balance. The second component of the package was directed at removing the distortions in the incentive structure and thereby facilitating production as well as restoring broken down social and economic infrastructure. During ERP II (July 1987-July 1990), the structural adjustment phase of the programme was undertaken. The emphasis here was to deepen further the reforms of the previous phase and to make good the weaknesses in the economy particularly in the area of institutions. Period average inflation came down from $50 \%$ per annum in the early reform years to $27 \%$ for 1987-1993. The third phase of the reform years could be described as the accelerated growth phase (1993-2000). Macroeconomic targets included $8 \%$ growth and the reduction of inflation to $5 \%$ by 2000 , among others. The targets not withstanding, over the entire period of the reforms, 1983-2000, inflation averaged $34 \%$ per annum. Even though there were occasions when inflation was brought down (to as low as $10 \%$ in 1985), these could not be sustained. Hence, it would be fair to state that over the reform period inflation management was clearly an unsuccessful enterprise. 


\section{Persistence of inflationary spells}

$\mathrm{D}$ ornbusch and Fisher's (1993) framework is adopted for describing the persistence of inflation in Ghana over the study period. As in Dornbusch and Fisher, our descriptive analysis addresses three key questions: How persistent has inflation in Ghana been over the years? For the moderate inflation episodes, where did the country come from? And lastly, where did Ghana go from the moderate inflation spell? An analysis of the degree or extent of inflation persistence is important in isolating the periodic supplyshock induced inflation episodes in ascertaining the causes of the persistence.

Clear patterns of moderate inflation can be observed in Table 2, which identifies four such episodes since 1960. The earlier moderate inflationary episode witnessed in the last three years of the post-independence administration of Kwame Nkrumah (19641966) preceded a period of low inflation (i.e., average period inflation rate of $8.7 \%$ ). From the first moderate inflationary regime the country again drifted back into a relatively lower inflationary spell, during which inflation averaged $2.3 \%$ per annum for three years.

Table 2: Episodes of persistent moderate inflation since 1960

\begin{tabular}{lccc}
\hline & \multicolumn{3}{c}{ Average period inflation } \\
\hline $\begin{array}{l}\text { Period of moderate } \\
\text { inflation }\end{array}$ & During the period & $\begin{array}{c}\text { Three years before } \\
\text { period }\end{array}$ & $\begin{array}{c}\text { Three years after } \\
\text { period }\end{array}$ \\
\hline $1964-1966$ & 22.7 & 8.7 & 2.3 \\
$1973-1975$ & 22.0 & 7.7 & 81.7 \\
$1986-1991$ & 27.2 & 57.7 & 20.0 \\
$2000-2002$ & 25.7 & 18.7 & $\mathrm{n} / \mathrm{a}$ \\
\hline
\end{tabular}

Note: $\mathrm{n} / \mathrm{a}-$ not available

a. Following Dornbusch and Fisher (1993) we define moderate inflation as annual inflation rate of $15-30 \%$ for at least 3 consecutive years.

Source: Author's computations based on data from World Bank's World Development Indicators, 2004.

The moderate inflation experienced during a period of vigorous macroeconomic reforms was incidentally the longest (1986-1991), most persistent moderate inflation spell ever experienced. The episode lasted six years, during which inflation averaged $27 \%$ per annum, with period average of the three preceding years reaching a high of $58 \%$ per annum (in 1984-1986). The 200)s began with another moderate inflation episode with a period average of $25.7 \%$ having come from inflationary experience where the three-year period average was $18.7 \%$. Unlike other countries that did not stay in moderate inflationary spells for long (see Dornbusch and Fisher, 1993), Ghana appears to have been saddled with persistent moderate inflation for far too long.

\section{Trends in output growth}

$\mathrm{T}$ rends in GDP growth over the past 43 years exhibit periods of both volatility and stability. GDP performance in the 1960s to the pre-reform period (prior to 1982) displayed significant ups and downs, with the country recording negative growth rates 
in certain instances (1965. 1971 and 1974). On the other hand, the period of reforms saw stability of growth consistently for more than 20 years (see Figure 2). Significantly, the two periods could also be described as periods where economic orientation was either towards interventionist or laissez-faire leanings. The reform period of stable economic grow th was associated with a liberal economic management paradigm, whereas the prereform years were periods where government controlled the commanding heights of the economy.

\section{Figure 2: Trends in output growth and inflation, 1960-2002}

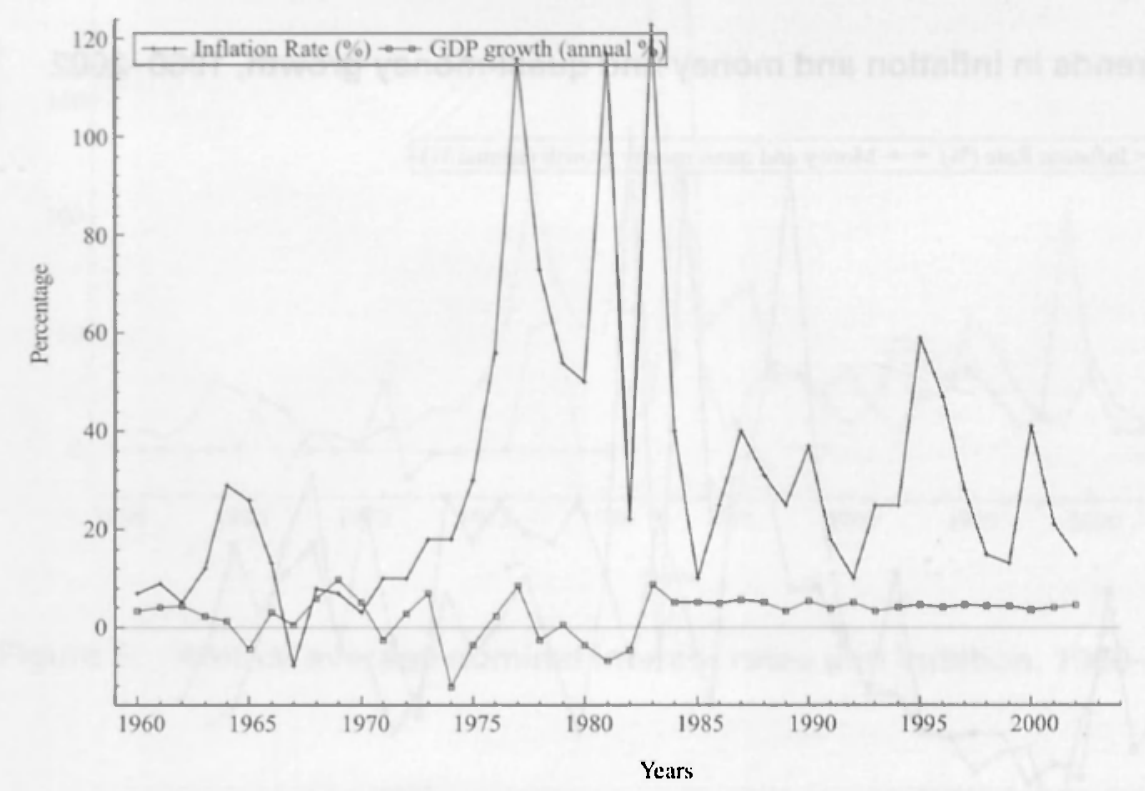

The paradox of Ghana's economic growth, however, is that during the period of steady growth inflation largely remained persistent and high in most years and at best moderate. Attempts to tame inflationary pressures, particularly over a period of strong reforms, were patently unsuccessful.

\section{Trends in inflation and monetary policy variables}

part from the surge in money supply recorded in $1964(37 \%)$, until 1971 money supply growth was barely more than $15 \%$ per annum. For the period 1972-1992, however, money supply growth was high and volatile. During the years of the Economic Recovery Programme (ERP), growth in money supply ironically persisted at an even higher pitch. The period average rate of growth in money supply was $43 \%$ per annum. The period 1992-2002 recorded somewhat of a slowdown in money supply from the pre-ERP levels as money growth levelled to $38 \%$ per annum.

Monetary authorities in Ghana have grappled with but failed to bring money supply under control. Indeed, its management has been as clusive as that aimed at inflation control. Generally, money supply has followed the trajectory of inflation performance (see Figure 3). Even though peaks in inflation have not exactly coincided with peaks in 
money supply, the two variables have by and large tended to bunch together. Interestingly, the high growth in money supply in the ERP years has stemmed from different sources. Unlike the pre-reform years, most of the changes came from changes in net foreign asset component (NFA) of broad money (Sowa, 1996). In the main, a good part of the NFA is used to acquire imported inputs for local production. It is therefore probable that the surge in prices as a result of increases in NFA may have been neutralized by increases in domestic output. Therefore, the effect of the increases in the NFA component of broad money supply may or may not have contributed to the moderate to high inflationary episodes witnessed in Ghana.

Figure 3: Trends in inflation and money and quasi-money growth, 1960-2002

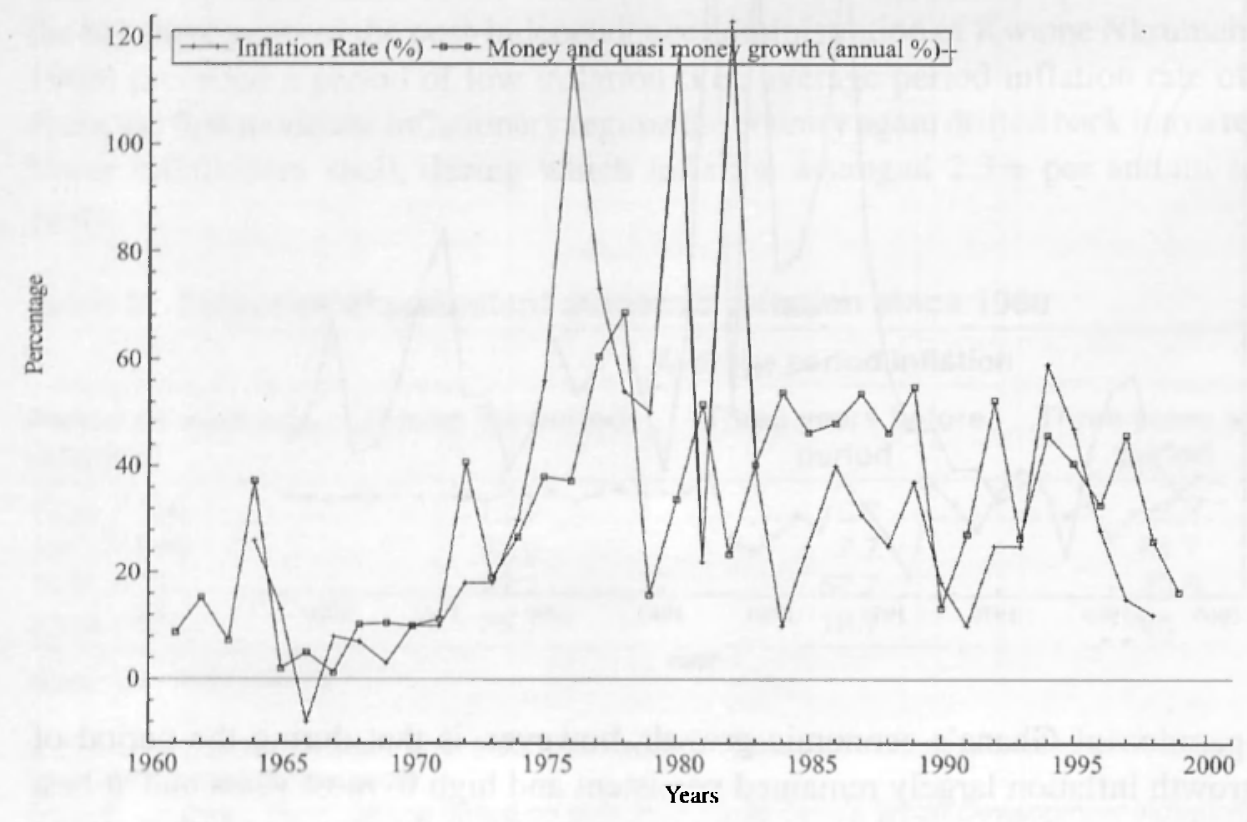

\section{Exchange rate}

(ienerally, exchange rate depreciation (or devaluation) and inflation in Ghana have tended to move together, as shown in Figure 4. In most instances depreciation rate traced the trijectory or lagged the course of inflation, hence indicating a strong relationship between the two economic phenomena. Over the period under discussion there were four major devaluations of the currency to the US dollar (i.e., 1967, 1971, 1978 and 1983). Each devaluation led to a sharp rise in inflation.

\section{Trends in inflation and interest rates}

The interest rate regime over the years can be characterized by two distinct subperiods. Apart from brief periods between 1960 and 1983, interest rate was mostly negative in real terms. The post reform years, on the contrary, were mostly characterized by positive real interest rate regimes with the exception 1990, 1996 and 2001. See Figure 5. 
A Mo: ell n of Ghana's Inflation Experience: 1960-2003

Figure 4: Trends in nominal exchange rate depreciation, 1960-2003

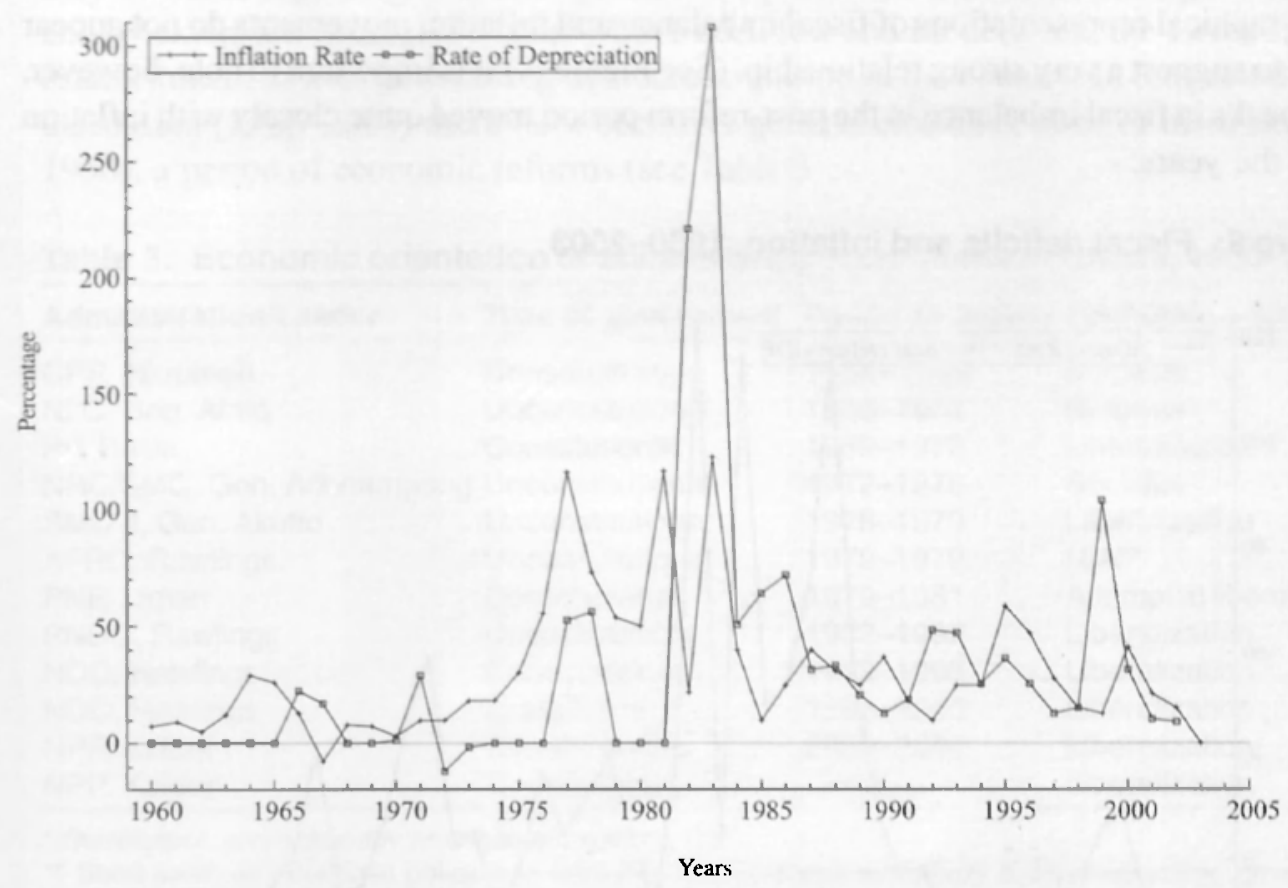

Figure 5: Annual average nominal interest rates and inflation, 1960-2003

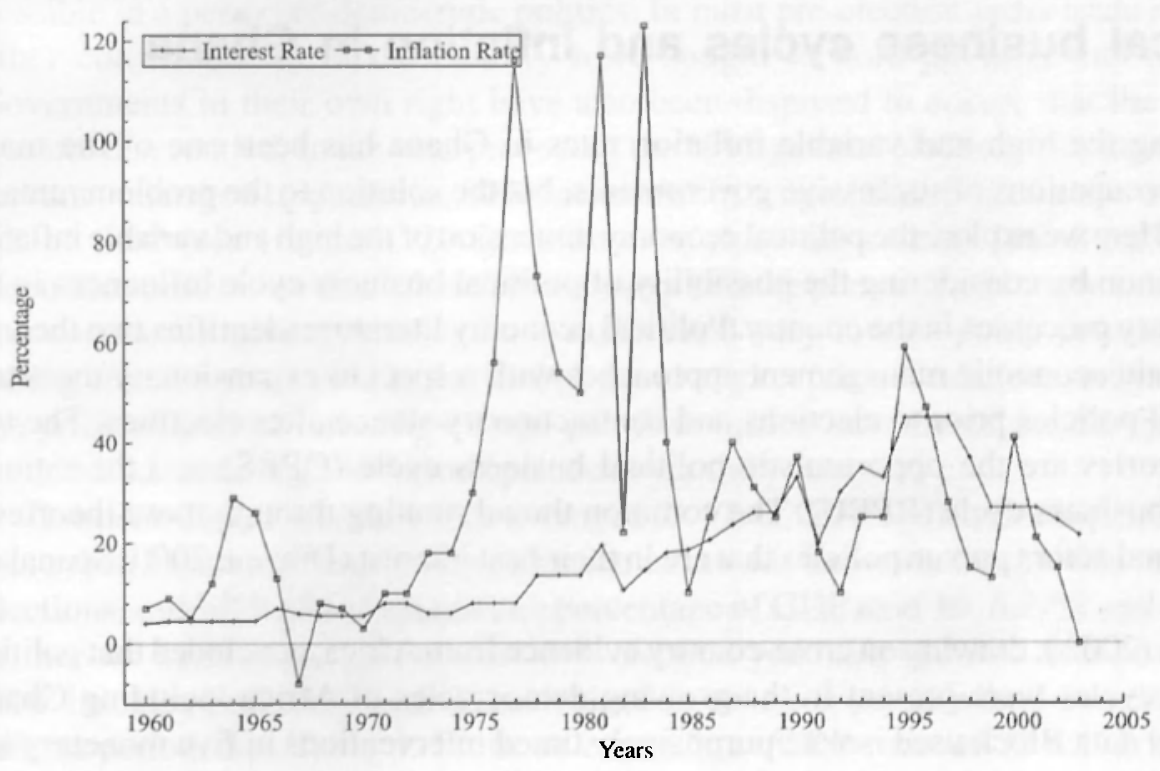




\section{Fiscal policy and inflation}

raphical representations of fiscal imbalance and inflation movements do not appear to suggest a very strong relationship. (See Figure 6.) It is important to note, however, that pcaks in fiscal imbalance in the post-reform period moved quite closely with inflation over the years.

Figure 6: Fiscal deficits and inflation, 1960-2003

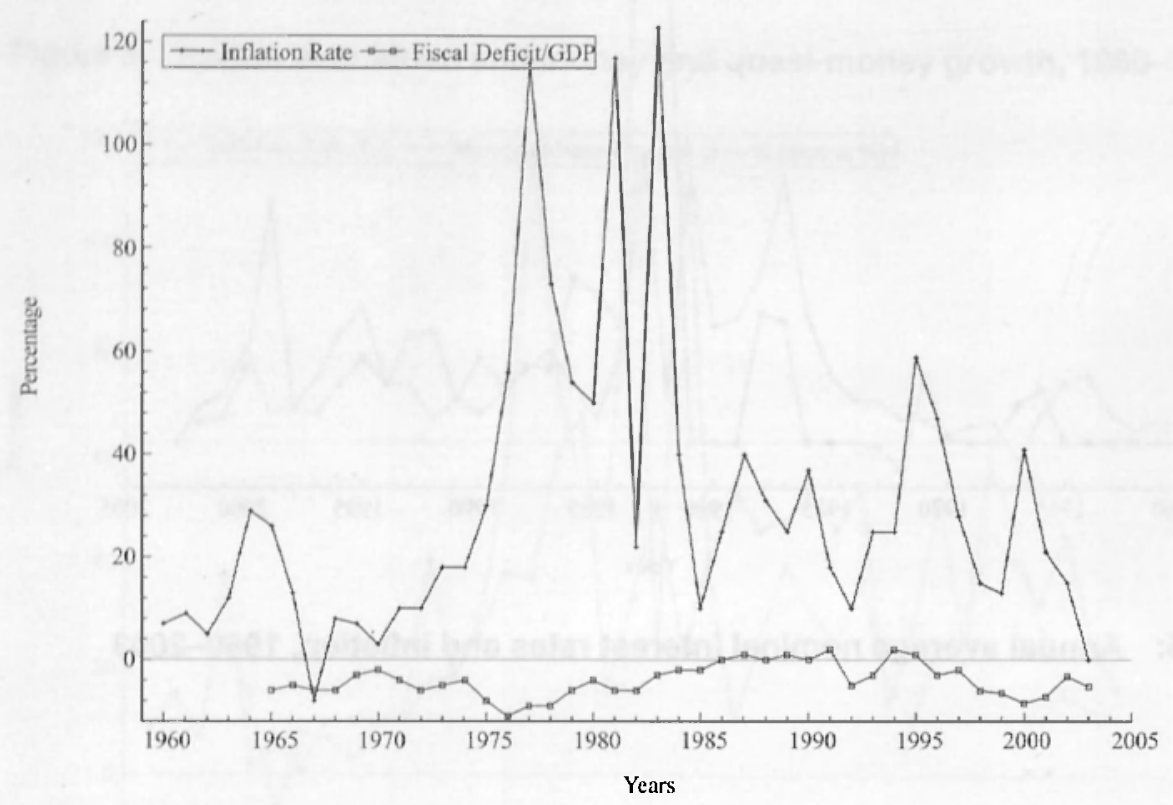

\section{Political business cycles and inflation in Ghana}

$\mathrm{T}$ aming the high and variable inflation rates in Ghana has been one of the major preoccupations of successive governments, but the solution to the problem remains elusive. ${ }^{5}$ Here we explore the political economy dimension of the high and variable inflation phenomenon by considering the possibility of political business cycle influences in the inflationary processes in the country. Political economy literature identifies two theories that explain economic management approaches with respect to expansionary monetary and liscial policies prior to elections and contractionary stance after elections. The two basic theories are the opportunistic political business cycle (OPBS) and the rational partisin business cycle (RPBC). The common thread running through these theories is that rational actors pursuc policies that are in their best interest (Drazen, 2000; Spanakos, 2() ()1).

Block (2002), drawing on cross-country evidence from Africa, concluded that political business cycles were present in the growing democracies of Africa including Ghana. The panel data Block used isolate purposively timed interventions in five monetary and fiscal policy variables in a pancl of 44 countries. His work conforms with the theory of 
rational opportunistic political business cycles. Given the persistent nature of inflation in Ghana a careful consideration of influences of political business cycles in intlation modelling may be worth exploring. Even though earlier experiments with democratic governance and by extension general elections - have been few and far between, the 1990s saw the establishment of a more enduring democratic culture in the country. In the period under discussion (1960-2003) there have been five general elections, three of them since the 1990)s, a period of economic reforms (see Table 3 ).

Table 3: Economic orientation of successive governments in Ghana, 1960-2003

\begin{tabular}{llll}
\hline Administration/Leader & Type of government & Period of regime & Economic orientation \\
\hline CPP, Nkrumah & Constitutional & $1954-1966$ & Socialist \\
NLC, Brig. Afrifa & Unconstitutional & $1966-1969$ & Reforms \\
PP, Busia & Constitutional & $1969-1972$ & Liberalization \\
NRC/SMC, Gen. Acheampong Unconstitutional & $1972-1978$ & Socialist \\
SMC II, Gen. Akuffo & Unconstitutional & $1978-1979$ & Liberalization \\
AFRC, Rawlings & Unconstitutional & $1979-1979$ & N/A** \\
PNP, Liman & Constitutional & $1979-1981$ & Attempt at liberalization \\
PNDC, Rawlings & Unconstitutional & $1982-1992$ & Liberalization \\
NDC, Rawlings & Constitutional & $1992-1996$ & Liberalization \\
NDC, Rawlings & Constitutional & $1996-2000$ & Liberalization \\
NPP, Kufour & Constitutional & $2000-2004$ & Liberalization \\
NPP, Kufour & Constitutional & $2004--$ & Liberalization \\
\hline
\end{tabular}

* Stabilization and a standby arrangement with the IMF.

* Short lived; no economic policy was implemented. This was essentially a "housecleaning" government aimed at stamping out corruption.

Source: Author's own compilation.

Pre-election experiences with the variable performances of monetary and fiscal policies have been less than satisfactory. Haynes (1995) observes that the difficult economic reforms carried out in the early 1980s with much vigour probably could not have been possible in a period of democratic politics. In most pre-election years trade unions and other constituencies in the country have sought to hold governments to ransom. Governments in their own right have also been disposed to ensure that the electorate was not disgruntled. In the year preceding the 1992 general elections, for example, civil servants managed to obtain an $80 \%$ increment in wages, thus pushing the wage bill to $8 \%$ of GDP (see Hutchful, 2002). Moreover, since the coming into force of the 4 th Republic constitution that ushered the country into the present multi-party constitutional era, successive administrations have maintained very low ex-pump petroleum prices during election years even in the face of world market price escalations, only lo increase the price after elections. These huge petroleum price increments ${ }^{6}$ are thought to have contributed to the high inflation episodes over the years.

Overall budget balance, which averaged $-0.4 \%$ of GDP in the reform years increased more than tenfold during the first election in the 4th Republic (i.e., 1992). In the 1996 elections, overall budget balance as a percentage of GDP $\operatorname{rose}^{7}$ to $-5.27 \%$ and worsened ${ }^{8}$ further to $-8.5 \%$ at the end of the 2000 election year. Expenditure as a proportion of GDP has also been very high in each election year compared with the average lor the reform period. See Table 4. From an expenditure/GDP ratio of $12.6 \%$ in the reform years, it deteriorated to $18 \%$ for the 1992 election year and to $25 \%$ in the 2000 election year. 
Table 4: Descriptive statistics for selected macroeconomic variables

\begin{tabular}{lrrrr}
\hline Macroeconomic indicator & $\begin{array}{c}\text { Period average } \\
\text { 1984-1991 }\end{array}$ & 1992 & 2000 \\
\hline Claims on governments, etc. (annual growth as \% of M2) & 42.5 & 34.7 & 21.4 & 49.5 \\
Current account balance (\% of GDP) & -2.5 & -5.9 & -4.7 & -7.8 \\
GDP growlh (annual \%) & 5.2 & 3.9 & 4.6 & 3.7 \\
Inflation, consumer prices (annual \%) & 38.8 & 10.1 & 46.6 & 25.2 \\
Money and quasi money growth (annual \%) & 43.8 & 52.3 & 39.2 & 54.2 \\
Overall budget balance, including granls (\% of GDP) & -0.4 & -5.2 &.. & -8.5 \\
Subsidies and other current transfers (\% of total expenditure) & 12.7 & 19.9 & 5.87 &.. \\
Tax revenue (\% of GDP) & 10.5 & 10.8 & 16.5 & 16.1 \\
\hline
\end{tabular}

Source: World Bank, World Development Indicators, 2004.

From the foregoing it can be argued that political business cycles appear to be evident in macroeconomic management in the country over the past two decades. However, the question of whether these cycles help in explaining the experiences of inflation management is an issue that the empirical component of the present paper intends to examine. 


\section{Methodology}

$\mathrm{H}$

ere we discuss the theoretical framework and data issues underlying this study. The section also presents empirical estimations and diagnostics, among others.

Johansen's cointegration test (Johansen, 1988) is used to examine the presence or otherwise of long-run relationships among the variables that are thought to drive inflation in Ghana. The error correction terms obtained from the long-run relationships were then used to account for the long-run effects in the single equation short-run dynamic model for inflation.

\section{Theoretical framework}

rawing on the standard and dominant theoretical underpinnings for inflation in small open economies, it is assumed that the price level is driven by money demand and imported inflation. It is therefore assumed that changes in the domestic price level are the result of deviations in the long-run equilibrium of the money and foreign exchange markets (i.e., purchasing power parity relationship-PPP). Some of the studies that have taken this approach are Juselius (1992), Durevall and Ndung'u (1999), Sacerdoti and Xiao (2001), and Nachega (2001). The relationship may be formally written as:

$$
m-p=\gamma_{0}+\gamma_{1} y+\Re
$$

where $m$ is the logarithm of money stock, $p$ is the logarithm of domestic price level, $y$ is the logarithm of output $9 i$ and is a vector of rates of returns on various assets. The longrun external sector equilibrium is also given by:

$$
p=q+e+t o t
$$

where $q$ is the logarithm of foreign price level, $e$ is the logarithm of exchange rate (this is given as foreign currency unit per a unit of domestic currency) and tot is the logarithm of the index of terms of trade. The tot term in the long-run equilibrium for the external sector is motivated by the fact that the standard PPP breaks down for Ghana because of the non-stationarity of the real exchange rate. The inclusion of the tot term is also in line with the hypothesis that relative prices between exportables and importables should lead adjustment in the real exchange rate. However, it is noted that non-stationarity typically observed in PPP studies has been associated with the use of overall price levels 
as against price of traded goods and to non-linearity in the PPP relationships. This is a data weakness that the present paper acknowledges.

When it can be confirmed that equations 1 and 2 represent cointegrating relationships, then a single-equation error correction model (ECM) for inflation in Ghana that incorporates feedback from the monetary and external sectors can be formulated. The ECM may be represented as:

$$
\begin{aligned}
& \Delta p_{i}=\alpha_{0}+\sum_{i=1}^{n-1} \varphi_{1 i} \Delta p_{t-i}+\sum_{i-1}^{n-1} \varphi_{2 i} \Delta m_{t-1}^{s}+\sum_{i=1}^{n-1} \varphi_{3 i} \Delta y_{t-1}+\sum_{t-1}^{n-1} \varphi_{4 i} \Delta \Re_{t-1}+\sum_{i=1}^{n-1} \varphi_{5 i} \Delta e_{t-1}+\sum_{i=1}^{n-1} \varphi_{6 i} \Delta q_{t-1} \\
& +\alpha_{1}\left(m-p-\gamma_{1} y-\gamma_{2} \Re\right)_{t-1}+\alpha_{2}(p-e-q=t o t)_{t-1}+\varphi_{7 i} D_{t}+v_{t}
\end{aligned}
$$

The sign $\Delta$ denotes the difference operator; $D_{i}$ is a vector of deterministic variables including centred seasonal dummies and impulse response dummies as well as a dummy accounting for political business cycles in the economy. The error correction terms are obtained as residual from the long-run relationships in equations 1 and 2. Thus, the difference between the actual levels of money and its predicted value as well as the actual level of domestic price and its predicted value captures the respective long-run effects. Consequently, by construction Equation 3 has both long-run and short-run components. The coefficients of the error correction terms measures the proportion of the disequilibrium that is transmitted onto the rate of inflation in each given period. The variables in differences constitute the short-run component of the inflation model.

The specification in Equation 3 relates inflation in period $t$ to current and lagged values of money supply, real income, opportunity cost of holding money, exchange rate depreciation, foreign prices, and the error correction terms from the monetary and external sectors. The two error correction terms represent the short-run responses required to move money stock and domestic price to their long-run equilibrium levels. If the absolute value of an error term is less than unity the adjustment process is said to be stable, and $m_{t}$ and $p_{t}$ adjust towards their long-run values. The closer the terms are to unity, the faster the adjustment process (see Alogoskoufis and Smith, 1991). The a priori expectations of the signs of money, exchange rate, foreign price and output are positive. However, the opportunity cost of holding money is expected to have a negative sign. Lagged inflation is thought of as a measure of inflation inertia. The coefficient of lagged inflation is expected to be zero when there is no inflation inertia. The inertia is usually interpreted as measuring indexation or inflation expectations. In Ghana, indexation has not been a practice; rather, inflation expectations have been built up over the years - and possibly more during the reform period - because of the failure of the monetary policy authorities to stabilize prices. Consequently, an appreciable level of inflation inertia is expected from the empirical estimations.

Given that Equation 3 can be solved for $p_{t}$ on the left-hand side, it is important to note that it can be useful in determining both the logarithm of price as well as the level of inflation. The equation also appears to present a general inflation model that incorporates other models as well, one of which is the monetarist model following Harberger (1963). In the monetarist model, excess money supply determines prices and inflation. This is the pure monetarist situation in which only variables that enter the demand for money component of the system in Equation 3 would be significant. The 
other form of inflation model represented in the system is based on the law of one price. The assumption here is that the law of one price holds for tradeable goods; in other words foreign inflation influences domestic inflation (Moser, 1995). Thus, the requirement for the monetarist model is that the error correction term from the monetary sector enters Equation 3 significantly and for the law of one price, the crror correction term from the external sector enters significantly. Another way of looking at the role of the external sector in driving inflation is to consider the relative price between non-tradeable and tradeable goods and their deviation from the equilibrium (see Durevall and Ndung' $u$, 1999, for a discussion of the relationship).

\section{Data and unit root tests}

Il the data series were quarterly in nature and they span the period 1960.1 to 2003.t. The consumer price index. CPI was the general price variable in the analysis. Money plus quasi money (M2+) in billion cedis was used to account for money stock with exchange rate as local currency units per one US dollar. We defined the interest rate series as the Government of Ghana three-month treasury bill discount rate; this was used as a proxy for the opportunity cost of holding money. GDP figures were used to represent output. Unlike the other series. GDP was an annual series that was interpolated to obtain a quarterly series. The weighted average wholesale price of Ghana's major trading partners was considered as a proxy for foreign prices. The terms of trade variable, $t o t$, was also defined as the relative price of the country's major exports to imports. The stylized facts of the previous section discuss certain key features of the performance of inflation and some of the other variables under discussion.

Possible seasonality in the data series is addressed by including centred seasonal dummies in the estimated models. The standard augmented Dickey-Fuller (ADF) unit root tests suggested that all the variables were non-stationary in levels. Like Sacerdoti and Xiao (2001), we found that the real exchange rate was not stationary, thus indicating that the strong version of the purchasing power parity hypothesis is not confirmed in the sample. See Appendix Table Al for results of unit root tests. It is noted, however, that the standard ADF test may not be appropriate in the presence of seasonality in the series.

\section{Empirical estimation}

$\mathrm{F}$ ollowing the formulation of the hypothesis that two long-term relationships exist, there are two options open for estimation. One is a composite system that includes all variables ( $m, p, y, q, e, t o t, 9 i)$ of the two subsystems relating to equations 1 and 2 . The other approach is to estimate the two subsystems separately. However, empirical work has established that large vector autoregression models are inherently difficult to estimate and that when many variables are included in a VAR, interpreting the cointegrating space becomes burdensome (Juselius, 1992). This paper therefore follows attempts at deriving long-run relationships from sectoral VARs (Jusclius, 1992; Metin, 
1995; Sekine, 2001). Rather than testing the existence of cointegrating vectors from the full matrix (П) represented by equations 1 and 2 , the system is decomposed into two subsystems (i.e., $\Pi_{1}$ and $\Pi_{2}$ ) representing the money and external markets.

The error correction terms in the two identified vectors representing the long-run relationships for the monetary and external sectors are then entered into the short-run inflation model. Studies that have used similar approach at modelling inflation in Africa have been Durevill and Ndung'u (1999) for Kenya, Nachega (2001) for Uganda, and Sacerdoti and Xiao (2001) for Madagascar. On the other hand, Jonsson (1999) used the composite approach in studying inflation in South Africa among other issues. The sectoral approach can also be seen as adding identifying restrictions to the full system, hence the approach permits the analysis of the short-run dynamics within the context of the full system (Sacerdoti and Xiao, 2001). In this study we follow these previous approaches to partitioning the VAR.

A vector of endogenous variables $x$ integrated of order $\mathrm{I}(1)$ can be tested for cointegration by estimating the VAR encompassing the endogenous variables. The Johansen cointegration analysis is performed on the unrestricted VAR using a maximum likelihood estimator (Johansen, 1988). The objective is to estimate the long-run matrix $\mathrm{I}$, and subsequently determine its rank, which also indicates the number of cointegrating vectors in the VAR. The matrix $\Gamma$ can then be factorized as $\Gamma=\alpha \beta$. Whilst $\beta$ is a matrix of cointegrating vectors $(r), \alpha$ is a matrix of factor loadings. A vector identification problem arises if $r>1$. The problem is addressed by imposing restrictions on the parameters in the $\alpha$ and $\beta$ matrixes. It is only after the identification of the long-run vector that meaningful economic interpretation can be assigned to the relationship.

\section{Monetary sector}

The estimation was undertaken with a VAR encompassing lags on prices, money, output and interest rate. Also included in the VAR were a constant, centred seasonal dummies and four impulse dummies to account for prominent outliers. ${ }^{9}$ Following insights from the stylized ficts discussed earlier, another dummy was included to account for political business cycles. The political business cycle dummy took on the value of unity in preelection" years and zero otherwise. All the deterministic variables entered the VAR in an unrestricted way.

A system reduction exercise was undertaken to obtain system specification test information to help decide the most appropriate lag length. Since quarterly data were used, we began the estimation with lag four. First we ascertained the significance of the individual variables in the VAR and found that all of them were significant save the political business cycle dummy. Test of significance of each lag also indicated that lags three and four were not significant. Test for model reduction from lag four to three was not statistically significant. "Consequently, we selected lag three as the most appropriate lag length. The significance tests for the variables and lags are presented in the Appendix, tables $\mathrm{A} 2$ and A.3.

Thus the Johansen cointegration test was undertaken for the monetary sector VAR with lag three. Variables that entered the substantive VAR were money, price, income and interest rates. Other variables were deterministic in nature and these entered in an 
unrestricted manner. These were the impulse response dummies, for 1967.3, 1971.4, 1978.2 and 1983.2. Also included were centred seasonal dummies. The cointegration test indicated the existence of tho cointegrating vectors and the results are presented below. However, an examination of the beta vectors seems to show that none of them resembles a money demand function when the signs of the variables are considered. We therefore normalized the beta vectors with money and realized that one of the vectors was like a demand for money function. The standardized eigenvalues of the nonnormalized and normalized (i.e., with money) are presented in Table 5.

Table 5: Monetary sector: Johansen eigenvalues and associated test statistics

\begin{tabular}{cccc}
\hline $\operatorname{Rank}(\pi=\Lambda)$ & $\begin{array}{c}\text { Eigenvalue } \\
(i .)\end{array}$ & $\begin{array}{c}\text { Trace test } \\
\left(\lambda_{\text {race }}\right)\end{array}$ & $\begin{array}{c}\text { Maximum eigenvalue test } \\
\left(\lambda_{\max }\right)\end{array}$ \\
\hline 0 & & $78.88^{* *}$ & $39.05^{* *}$ \\
1 & 0.2265 & $39.83^{*}$ & $29.06^{*}$ \\
2 & 0.17403 & 10.77 & 9.92 \\
3 & 0.02240 & 3.44 & 3.44 \\
\hline
\end{tabular}

Note: Estimations from PCGive 10.

The second column of Table 5 outlines the estimated eigenvalues. The first two values are noticeably larger than zero, signifying the existence of two cointegrating vectors in the monetary system. The existence of two cointegrating vectors in the system is further underscored by the trace and maximum eigenvalue test statistics, respectively, which rejects the null hypothesis of no cointegrating vector at the $99 \%$ level of significance.

The results of the unrestricted four-variable VAR (3) are shown in Table 6. Standardized eigenvalues are presented for the $\beta$ and $\alpha$ matrixes, which represent long-run elasticities and their associated alpha coefficients accounting for short-run adjustment in the system. The signs of the various variables in the vectors do not conform exactly to the demand for money function represented in Equation 1 even though columns 1, 2 and 3 seem to have only one sign right, with wrong signs for the other variables in the moncy demand function. When the beta vectors were normalized on money, however, one vector was clearly identified to be associated with the money demand function as given in Equation 1. We present the two sets of VARs in tables 6 and 7.

Following the results of the normalization with money, the demand for money in Ghana over the study period may be written as:

$$
m-p-y+1.3274 i
$$

The money demand function above therefore represents the long-run demand for money in Ghana. The role of treasury bill rates in the money demand function underscores the potential of interest rates in the conduct of monetary policy in Ghana. 
Table 6: Monetary sector VAR (non-normalized)

\begin{tabular}{ccccc}
\hline & $m$ & $p$ & $y$ & $i$ \\
\hline Cointegrating vectors & & Standardized eigenvalues of $\hat{\beta}$ & \\
\hline$\hat{\beta}_{1}$ & 1.0000 & -0.7931 & 8.2653 & -5.2115 \\
$\beta_{2}$ & 0.85535 & 1.0000 & -4.1260 & -5.1777 \\
$\beta_{3}$ & 0.08836 & -0.16554 & 1.0000 & -0.0085 \\
$\hat{\beta}_{4}$ & -1.1213 & 0.7990 & 2.6493 & 1.0000 \\
\hline Adjustment terms & & Standardized eigenvalues of $\hat{\alpha}$ & \\
\hline$\hat{\alpha}_{1}$ & -0.1808 & -0.0084 & -0.0023 & 0.2883 \\
$\alpha_{2}$ & -0.0113 & 0.0164 & 0.0001 & 0.0124 \\
$\alpha_{3}$ & 0.1390 & 0.0424 & -0.0100 & 0.0027 \\
$\alpha_{4}$ & -0.0092 & 0.0010 & -0.0007 & -0.0113 \\
\hline
\end{tabular}

Note: All the cointegrating vectors are normalized on the betas. The estimation was for the period 1961.1 to 2003.4. The VAR included three lags on each variable, constant, centred seasonal dummies and four impulse dummies. The impulse dummies assumed the value of unity in 1967.3; 1971.4; 1978.2 and 1983.2.

Table 7: Monetary sector VAR with normalization on money

\begin{tabular}{ccccc}
\hline & \multicolumn{5}{c}{ Standardized eigenvalues of $\hat{\beta}$} \\
\hline Cointegrating vectors & $m$ & $p$ & $\boldsymbol{y}$ & \multicolumn{1}{c}{$\boldsymbol{i}$} \\
\hline$\hat{\beta}_{1}$ & 1.0000 & -0.4283 & 1.000 & 0.0545 \\
$\beta_{2}$ & 1.0000 & 0.0571 & -1.0623 & 1.5898 \\
$\beta_{3}$ & 1.0000 & -0.3143 & -1.0623 & 1.3274 \\
\hline Adjustment terms & & Standardized eigenvalues of $\hat{\alpha}$ & \\
\hline$\hat{\alpha}_{1}$ & -0.1808 & -0.0084 & -0.0023 & 0.2883 \\
$\alpha_{2}$ & -0.0113 & 0.0164 & 0.0001 & 0.0124 \\
$\alpha_{3}$ & 0.1390 & 0.0424 & -0.0100 & 0.0027 \\
\hline
\end{tabular}

\section{External sector}

The variables that entered the VAR for the external sector were exchange rate, domestic price, foreign price and terms of trade. Unlike the monetary sector, the dummy for the political business cycles was dropped because it was found to be statistically insignificant in contribution to the VAR. The system reduction test undertaken suggested a lag of four as the most appropriate lag length for the VAR estimation. This was determined 
using the F-test, the Akaike information criterion (AIC) and the Schwartz criterion (SC). Results of the Johansen test for cointegration for the external sector are shown in tables 8 and 9.

Table 8: External sector: Johansen eigenvalues and associated test statistics

\begin{tabular}{cccc}
\hline Rank $(\pi=\kappa)$ & $\begin{array}{c}\text { Eigenvalue } \\
(\lambda)\end{array}$ & $\begin{array}{c}\text { Trace test } \\
\left(\lambda_{\operatorname{mac}}\right)\end{array}$ & $\begin{array}{c}\text { Maximum eigenvalue test } \\
\left(\lambda_{\max }\right)\end{array}$ \\
\hline 0 & & $30.39^{* *}$ & $18.46^{* *}$ \\
1 & 0.016 & 0.11 & 0.11 \\
\hline
\end{tabular}

Table 9: External sector: VAR normalized on $p-e-q$

\begin{tabular}{ccc}
\hline & & \multicolumn{2}{c}{ Standardized eigenvalues of $\hat{\beta}$} \\
\hline Cointegrating vectors & $p-e-q$ & tot \\
\hline$\hat{\beta}_{1}$ & 1.000 & -0.57 \\
$\hat{\beta}_{2}$ & 1.000 & 1.286 \\
\hline Adjustment terms & & Standardized eigenvalues of $\hat{\alpha}$ \\
\hline$\hat{\alpha}_{1}$ & -0.0160 & 0.0241 \\
$\hat{\alpha}_{2}$ & 0.0133 & 0.0201 \\
\hline
\end{tabular}

Note: The beta matrix is normalized on $p-e-q$.

The maximum eigenvalues as well as the trace statistics from the unrestricted VAR suggest the presence of only one cointegrating vector. The signs of the first cointegrating vector were found to be consistent with the a priori assumptions. Hence, the long-run external sector equation for Ghana may be formally written as:

$$
p-e-q=0.57 \text { tot }
$$

The coefficient of tot (i.e., 0.57 ) obtained for the present study was more than twice that obtained for Madagascar (0.22) by Sacerdoti and Xiao (2001), and again far higher than the figure obtained for Kenya, 0.36, by Durevall and Ndung'u (1999).

\section{Weak exogeneity}

variable is said to be weakly exogenous in a system of error correction equation if
the error correction term does not enter the equation for that variable. This is
implemented by testing null hypothesis that the $\hat{\alpha}$ element of a corresponding $\hat{\beta}$
variable (from a cointegrating vector) is not significantly different from zero. The given
$\hat{\beta}$ coefficient is described as exogenous and can be left out of the system without 
altering the statistical properties of the test statistics of the cointegrating vector (Ericsson, 1998). The literature suggests that the distribution of the test statistics will be dependent on all other variables that prove not to be weakly exogenous. The system must therefore be estimated as a whole so as to enable one to make inferences about the cointegrating vector.

We found all but output to be weakly exogenous. Table 10 shows the p-values of the test statistic for testing whether money, output and interest rate were weakly exogenous. The implication is that money, price and interest rates will adjust over time to restore the long-run equilibrium following external shocks that lead to deviation of the system from its long-run equilibrium. It can therefore be argued that in a simultaneous equation representation of the system, error correction terms should be introduced in the equations for money, price and interest rates but not real income.

Table 10: Monetary sector: Tests for weak exogenelty

\begin{tabular}{lcc}
\hline Variable & $\chi^{2}(2)$ & p-value for the test statistic \\
\hline$m$ & 14.191 & 0.008 \\
$y$ & 3.63 & 0.163 \\
$p$ & 11.17 & 0.004 \\
$i$ & 6.67 & 0.035 \\
\hline
\end{tabular}

Similarly, the hypothesis of weak exogeneity was tested for the variables that entered the extcrnal sector VAR; the results are as presented in Table 11. In the external sector equation, weak exogenous hypotheses concerning foreign price and exchange rate were rejected.

Table 11: External sector: Tests for weak exogeneity

\begin{tabular}{lcc}
\hline Variable & $\chi^{2}(2)$ & p-value for the test statistic \\
\hline$\theta$ & 3.999 & 0.135 \\
$p$ & 16.624 & 0.002 \\
$q$ & 5.137 & 0.076 \\
tot & 12.73 & 0.002 \\
\hline
\end{tabular}

\section{Single error correction model for inflation}

ur development of a single error correction model for inflation in Ghana unfolds in the following manner. A general model is first estimated from which an empirically parsimonious model is derived. In the process the number of lags is reduced and insignificint explanatory variables dropped from the model. The reduction is undertaken using F-test and other information criteria such as the Schwartz criterion (SC).

The general model was estimated with four lags of each of the variables in first differences and the two error correction terms, $E C l=[m-p-y+1.3274 i]$ and $E C 2=[\mathrm{p}-\mathrm{c}-q=57 \mathrm{tot}]$. Other variables that entered the short-run dynamic model were a constant, centred seasonal dummies, a dummy for political business cycles and four impulse dummics. Following earlier studies, output and the terms of trade variables 
were dropped, mainly because they were thought not to contain information relevant for the short-run, but more so since they were obtained from interpolations. The parsimonious model is presented in Table 12.

Table 12: Parsimonious error correction model, 1961:2 to 2003:4

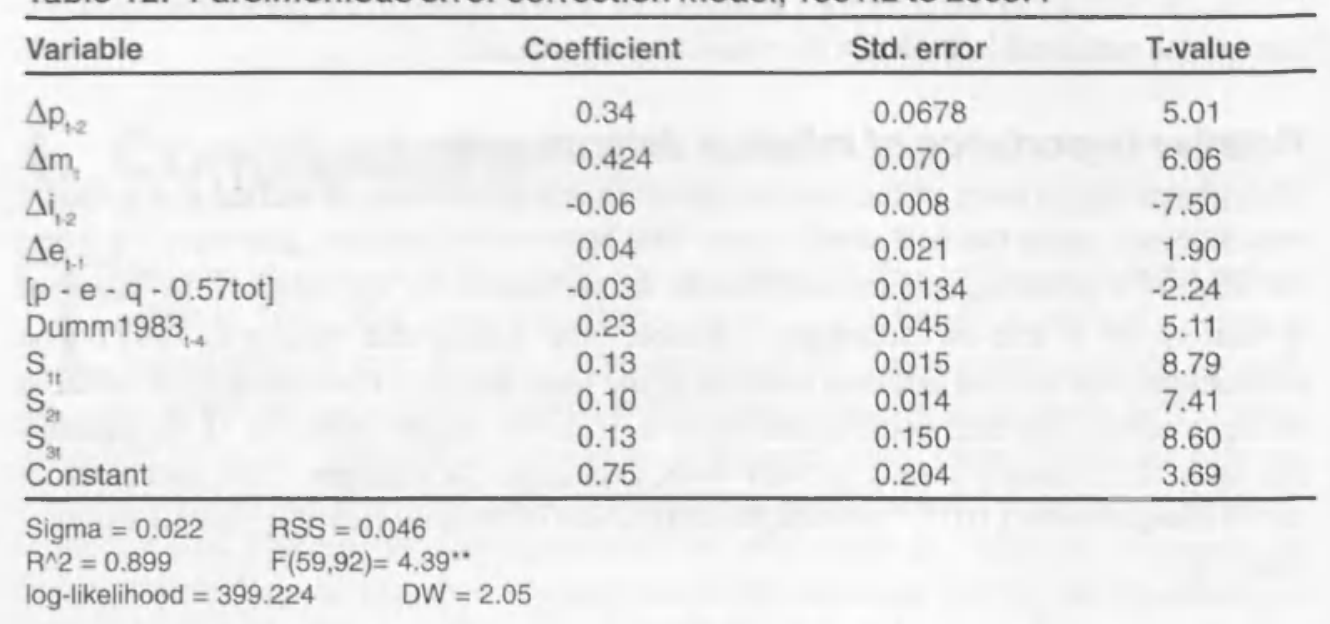

AR 1-5 test: $F(5,143)=0.27424$

Normality test: Chi^2(2) $=1130.1^{*}$

ARCH $1-4$ test: $F(4,140)=0.0073258$

RESET test: $F(1,147)=1.1597$

Hetero test: $F(42,105)=2.1764$

Past inflation was found to be a significant determinant of inflation in the short run. The coefficient of 0.35 for lagged inflation suggests the presence of substantial inflation inertia. Changes in growth in money stock and the Government of Ghana treasury bill rate were also found to be potent in the movement of inflation. The two variables were positively related to inflation movements. The coefficient of -0.049 for the error correction term for the external sector indicates a relatively low rate of adjustment in the external sector. Thus, barely $5 \%$ of the adjustment in the external sector is corrected every quarter. Whilst exchange rate appeared significant, foreign price and terms of trade changes do not seem to affect inflation directly in the short run; rather, their effects are transmitted through the error correction mechanism.

It also appears that excess money supply does not determine inflation in the long run, given that the error correction term representing the monetary sector does not enter the short-run model significantly. Stylized facts discussed earlier tended to suggest a possible role for political business cycle in inflation dynamics. Even though the deterministic variable for the political business cycle was found to have a role in price level determination in the long run, in the short run the variable was not significant. Food price and petroleum price shocks did not enter the modelling at any stage because of the poor statistical properties of the variables, hence they were dropped.

\section{Diagnostics}

Statistical properties of the model were evaluated with a range of test statistics in order to validate the results. The model appears to be statistically well specified. In addition to the relatively high $\mathrm{R}^{2}$, there seems to be no evidence of serial correlation (AR test) or 
autoregressive heteroscedasticity (ARCH test). The model can be said to have been well specified since the assumption that the model was well specified was not rejected (RESET test). However, the assumption about normally distributed errors could not be accepted. Generally, it can be argued that the residuals appear to be well behaved. Exclusion tests undertaken for the variables that were dropped in the parsimonious shortrun model indicated F-statistics that were not significant.

\section{Relative importance of inflation determinants}

The relative importance of the various determinants of inflation identified in the model was assessed using the beta coefficients. The beta coefficients are generated by using the size of a given regression coefficient, $\kappa$, multiplied by the ratio of the standard deviations of $\kappa$ and the dependent variable (see Ndulu and Ndung'u, 1997). The estimations indicate that inflation inertia was the most important determinant of inflation in the country. The beta coefficients were as follows: lagged inflation, 0.30 ; treasury bill rates, 0.22 ; money supply growth, 0.18 ; exchange rate changes, 0.08 ; and external sector disequilibrium, 0.05 . The unexplained portion of the importance weighting exercise was 0.17 . 


\section{Conclusions}

$\mathrm{T}$

he primary concern of the study was to model inflation in Ghana over the period 1960 to 2003. The paper traced the country's intlation ary experience drawing on selected stylized facts from the immediate post inde pendence period through the years of reform up to 2003. Persistent intlation spells during the study period were identified using an approach developed by Dornbusch and Fisher (1993). An attempt was also made to assess the likely role of political business cycles in determining intlation in the country. The empirical component of the study used the Johansen cointegration test in ascertaining the presence or otherwise of the existence of long-run relationships among the variables that constitute the monetary and external sectors. An error correction model representation of the two cointegrating vectors encompassing the monetary and external sectors of the economy was estimated to help explain inflition in Ghana.

Even though we initially wanted to look at the effects of petroleum prices in determining inflation, the paucity of data on domestic ex-pump price of petroleum products covering the study period prevented the inclusion of the variable in the investigations. Aggregate food price shock (defined as the difference between food price inflation and CPI inflation) was also dropped from the analy sis because the statistical properties of the series were not good enough to enter the est imation process. These challenges can be seen as weaknesses that can be addressed in fut ure attempts at modelling inflation in Ghana. It is important to indicate, however, that various constraints notwithstanding certain indicative lessons can be drawn from the study. The result of the study is consistent with the work of Bawumia and Atta-Mensah (2003), who argue that inflation in Ghana is a monetary phenomenon.

First, the findings identify exchange rate, foreign prices and terms of trade as determinants of prices in the long run. The adjustment of inflat ion to disequilibrium in the external sector is slow with just about $4 \%$ of the disequilibri um corrected in a given quarter. Like Durevall and Ndung'u (1999), we failed to find evidence suggesting the influence of excess money supply on inflation, as the error correction term from the monetary sector did not enter the error correction model signifi c antly. Money may have affected prices indirectly through other variables, but this is an issue that our study did not explore.

In the short run, inflation inertia, money growth, changes in treasury bill rates and the exchange rate were found to be important in determining the level of inflation. The effects of the four variables conformed to our a priori assumpt i ons. Whilst the effect of foreign price was not significant in the short run, its impact is transmitted through the error correction mechanism from the external sector. Inflation inertia was the dominant 
determinant of inflation in the short run, followed by growth in money and changes in the treasury bill rates and the exchange rate. Inflation inertia is captured in the single equation error correction models as the coefficient of lagged inflation (see Killick and Mwega, 1989).

The study affirms the usefulness of the treasury bill rate as a nominal anchor for inflation management, even though the effectiveness of the instrument appears to have been compromised by the high inflation expectations in the economy. The high inflation inertia identified by the study may have come about as a result of the scepticism harboured by households and producers about the central bank's capacity to maintain price stability. Agenor (2004) identifies the independence of the central bank as a prerequisite in forestalling high inflation expectations. Therefore, it is important that efforts be made to inspire confidence among households and firms in the central bank's renewed commitment and ability to ensure price stability. In order to achieve this goal the independence of the central bank must be guaranteed. Fortunately, certain new laws that safeguard the bank's independence have recently been promulgated. These laws provide for the establishment of a Monetary Policy Committee (MPC) that has since been put in place. It is essential that the MPC move swiftly to drive down inflation expectations. It is believed that when inflation inertia is considerably reduced, the full benefits of using interest rates as nominal anchor may be realized.

Although exchange rate was used as one of the nominal anchors in the pre-reform period, its present role in inflation determination, particularly in the short run, does not appear to be prominent according to the results of this study - more so since its importance weighting (i.c., beta coefficient) appears quite low compared with inflation inertia, money growth and treasury bill rate changes. Nonetheless, the variable cannot be completely overlooked in managing inflation. Foreign prices and terms of trade are factors that monetary authorities have no control over, hence their role in inflation performance ought to be seen in terms of shocks that need to be managed. 


\section{Notes}

1. The North Carolina Summit. 1995.

2. This was the first stabilization programme that the country ever undertook.

3. Many of the public farm complexes started by the previous administration were privatized. Work on other industrial complexes being undertaken with support from Nkrumah's socialist friends in Eastern Europe and Russia was stopped abruptly.

4. The National Redemption Council later became Supreme Military Council (SMC).

5. The accelerated growth phase of the economic reform pursued in Ghanat targeted an inflation rate of $5 \%$ by the year 2000; the reality has proved the target a mirage (Hutchful, 2(0)2: 57 ).

6. In February 2001, following the elections of the year 200), the New Patriotic Party (NPP) administration increased the prices of petroleum by over $90 \%$ after the previous National Democratic Party (NDC) administration failed to adjust prices because of the elections. In 2004. despite the high world oil prices that crossed the US\$50/barrel mark, the NPP government maintained the low price and ended up subsidizing petroleum products to the tune of US $\$ 200$ million, i.e., $2.5 \%$ of GDP.

7. Before the elections in 1996 the government set afoot a huge public-works programme, padding contracts to pay off important interest groups (The Economist, 2002).

8. It is reported that prior to the 2000 elections the ruling government actually handed out fistfuls of cash to voters to woo them at a time when gold and cocoa, the major foreign exchange earners for the country, had plummeted in prices (The Economist, 2002).

9. The impulse dummies used were the following: devaluations of 1967.3, 1971.4 and 1978.2 and the austere budget presented in 1983.2 that involved a huge devaluation, among other policy regimes.

10. The study considered only the elections following the new democratic dispensation in Ghana that was ushered in by the 4th Republic Constitution prior to the elections of 1992.

11. We dropped lag four and left lag three because an attempt to drop lag three resulted in the cointegration test indicating more than four cointegrating vectors, thus making identification difficult. 


\section{References}

Adam. C., B. Ndulu and N.K. Sowa. 1996. "Liberalization and seigniorage revenue in Kenya, (Ghana and Tanzania". The Journal of Development Studies, 32(4, April): 531-53.

Agenor, P.R. 2004. "The macroeconomics of poverty reduction". Centre for Growth and Business Cycle Research Discussion Paper Series 43. The School of Economic Studies, The Univeristy of Manchester.

Alogoskoufis, G. and R. Smith. 1991. "On error correction models: Specification, interpretation, estimation". Journal of Economic Surveys, 5(1): 97-128.

Atta, J.K, K.R. Jefferis and I. Mannathoko. 1996. "Small country experiences with exchange rates and inflation: The case of Botswana". Journal of African Economies, 5(2): 293-326.

Bawumia, M. and J. Atta-Mensah. 2003. "A simple vector-error-correction forecasting model for Ghana". Working Paper, MAFSD, Bank of Ghana. February.

Bhalla, S.S. 1981. The Transmission of Inflation into Developing Economies. Washington, D.C.: The Brookings Institute.

Block, S.A. 2002. "Political husiness cycles, democratization and economic reform: The case of Africa". Journal of Development Ecomomics, 67: 205-28.

Bramann, B. 2000). "Real effects of high inflation". Working Paper No. WP/(0)/85. Western Hemisphere Department, International Monetary Fund, Washington, D.C., May.

Catoal, L. and M.E. Terrones. 2003. "Fiscal deficits and inflation". Working Paper No. WP/03/ 65. International Monetary Fund, Washington, D.C., April.

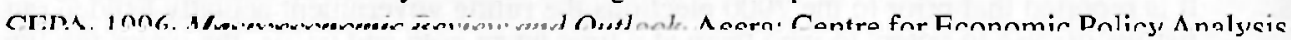

Chhibber. A. 1992. "Exchange reforms, supply response and inflation in Africa". In I. Goldin and L.A. Winters, eds.. Open Economies: Structural Adjustment and Agriculture. Cambridge: Cambridge University Press.

Chhibher, A. and N. Shaffik. 1991. "The inflationary consequence of devaluation and parallel market: The case of Ghana". In A. Chhibber and S. Fisher, eds., Economic Reform In SubSaluram Africa. A World Bank Symposium. Washington, D.C.: The World Bank.

Dordunoo, C. 1994. "The structure and policy implications of a macroeconomic model of Ghana". World Developme'nt, 22(8): 1243-51.

Dombusch, R. and S. Fischer. 1993. "Molerate inflation". The World Bank Ecomomic Review, 7(1): 1-44.

Drazen, Allan. 2000. "The political business cycle". Paper prepared for the NBER 5th Annual Macroeconomics Conference, Cambridge. Massachusetts, April.

Durevall, D. and N.S. Ndung'u. 1999. "A dynamic model of inflation for Kenya, 1974-1996". IMF: Working Paper 99/77. International Monetary Fund, Washington, D.C.

The Economist. 2002. "Ghana as economic model: Good but not at election time". 25 April, p.44.

Ficlgen, (i., K. Fixen and C. Odhiner. 1969. "Wages, growth and distribution of income". Sweclish Journal of Eionomics, 7 I(September): 11-60).

Fricsson. N. 1998. "Empirical modelling of money demand". Empirical Economics, 23(3): 295-315. 
FIAS. 2002. The Administrative Cost of Doing Busine'ss in Ghama. Foreign Investment and Advisory Service (FIAS) World Bank/DFID/LSAID.

Harberger. A.C. 1963. "The dynamics of inflation in Chile". In A.C. Harberger, N. Livithian, J. Mincer. Y. Mlundlak. M. Nerlove. D. Patinkin. L.G Telser and H. Theil. eds.. Me'asure'me'nt in Economics: Studies in Mathematical Economics and Econometrics in Me'mory of Ye'huda Grunfield. Chicago: L'niversity of Chicago Press.

Haynes, J. 1995. “Ghana: From personalistic to demoxratic rule”. In J.A. Wiseman, ed., De'mocracy" and Political Change in Sub-Saharan Africa. London: Routledge Press.

Hendry, D.F. and J. A. Doomik. 2001. Empirical Ecomome'tric Mode'lling Using PCCive'. London: Timberlake Consultants Press..

Hutchful, Eboe. 2002. Ghana's Adjustme'nt Experie'nce. The' Paradox of Reform. United Nations Research Institute for Social Development (INRISD). London: James Currey; Oxford: Woeli.

Johansen. S. 1988. "Statistical analysis of cointegration vectors". Journal of Ecomomic Drnamics and Control, 2 (June-September): 231-54.

Jonsson. Gunnar. 1999. "Inflation, money demand and purchasing power parity in South Africa". IMF Working Paper 99/122. International Monetary Fund, Washington, D.C.

Juselius, K. 1992. "Domestic and foreign price effects on prices in an open economy: The case of Denmark". Journal of Policy Modelling, 14: 401-8.

Killick. T. and F. M. Mwega. 1989. "Monetary policy in Kenya, 1967-88". ODI WorkingPaper, No. 39, July 1990.

Lim, C.H. and L. Papi. 1997. "An econometric analysis of the determinants of inflation in Turkey". IMF Working Paper No. WP/97/170. International Monetary Fund. Washington, D.C.

Loungani. P. and P. Swagel. 2001. "Sources of inflation in developing countries". IMI: Working Paper No. WP/01/198. International Monetary Fund, Washington, D.C.

Metin. K. 1995. "An integrated analysis of Turkish inflation". Oxford Bulletin of Economic and Statistics, 57: 513-31.

Moser, GG 1995. "The main determinants of inflation in Nigeria". IMF Staff Papers; Vol. 42 (2): 270-89.

Nachega, J.C. 2001. "Financial liberalization, money demand and inflation in Uganda". IMF Working Paper No. 01/1 18. International Monetary Fund, Washington, D.C.

Ndulu. B. J. and N. S. Ndung 'u. 1997. "Trade and growth in Sub-Saharan Africa," A paper presented at the IMF/AERC Seminar on Trade Reforms and Regional Integration in Africa, Washington, D.C., 13 Decenber 1997.

Parkin, M. 1977. "A monetarist analysis of the generation and transmission of world inflation: 1958-71". American Economic Review, 67(1): 164-71.

Sacerdoti, E. and Y. Xiao. 2001. "Inflation dynamics in Madagascar, 1971-2000). IMF Working Paper No. 01/168. International Monetary Fund, Washington, D.C.

Sani. K.G 1982. "The monetarist explanation of inflation: The experience of six Asian countries". World Development, 10(10): 871-84.

Sekine, T. 2001. "Modelling inflation and forecasting in Japan". IMF Working Paper No. 01/82. International Monetary Fund, Washington, D.C.

Sowa, N.K. 1994. "Fiscal deficit, output growth and inflation targets in Ghana". World Develoment, 22(8): $1105-17$.

Sowa, N.K. 1996. Policy Consistency and Inflation in Ghana. AERC Research Paper No. 43. African Economic Research Consortium, Nairobi, Kenya.

Sowa, N.K. and J. Kwakye. 1991. Inflationary Trends and Control in Ghana. AERC Research Paper No. 22. African Economic Research Consortium, Nairobi, Kenya.

Spanakos, T. 2001. "Political business cycles in emerging markets: The case of Brazil". Working Paper. Manhattanville College, Princeton University. 


\section{Appendix: Results of unit root and other tests}

Table A1: Unit root test for data series

\begin{tabular}{lccc}
\hline Series & Levels & $\begin{array}{c}\text { t-statistics } \\
\text { first differences }\end{array}$ & Order of integration \\
\hline$p$ & 1.64 & -5.38 & $\mid(1)$ \\
$y$ & -0.02 & -16.22 & $\mid(1)$ \\
$m$ & 1.59 & -10.40 & $\mid(1)$ \\
$e$ & 1.04 & -5.38 & $\mid(1)$ \\
$i$ & -1.29 & -7.30 & $\mid(1)$ \\
pps & -11.82 & & $\mid(1)$ \\
fps & -12.9 & & $\mid(0)$ \\
$q$ & -2.32 & -3.39 & $\mid(0)$ \\
p-e-q & -2.68 & & \\
\hline
\end{tabular}

Notes: Variables are in logs and the sample period span 1960.2-2003.4. The asymptotic critical values for the $\beta$ s are -2.878 for $5 \%$ and -3.469 for $1 \%$.

Source: Author's computations using PCGive 10 (Hendry and Doornik, 2001).

Table A2: Tests of significance of each variable: Monetary sector VAR

\begin{tabular}{lcrc}
\hline Variable & F-Test & Value & [Prob] \\
\hline$m$ & $F(16,394)$ & 41.15 & {$[0.00]$} \\
$p$ & $F(16,394)$ & 96.95 & {$[0.00]$} \\
$y$ & $F(16,394)$ & 47.34 & {$[0.00]$} \\
$i$ & $F(16,394)$ & 14.92 & {$[0.00]$} \\
D1 & $F(20,428)$ & 2.79 & {$[0.00]$} \\
D2 & $F(20,428)$ & 2.55 & {$[0.00]$} \\
D3 & $F(20,428)$ & 4.78 & {$[0.00]$} \\
Constant & $F(20,428)$ & 27.74 & {$[0.00]$} \\
Cseasonal & $F(4,129)$ & 3.46 & {$[0.01]$} \\
\hline
\end{tabular}

Note: Computations from PCGive 10. 
A Modeuing of Ghana's Inflation Experience: 1960-2003

Table A3: Test of significance of all lags up to 4: Monetary sector VAR

\begin{tabular}{lccccc}
\hline Variable & F-Test & Value & [Prob.] & AlC & SC \\
\hline Full model & & & & -8.8857 & -5.9578 \\
Lag 4-4 & $F(32,477)$ & 0.884 & {$[0.652]$} & -9.0454 & -6.7300 \\
Lag 4-3 & $F(64,507)$ & 1.403 & {$[0.640]$} & -9.1024 & -7.3540 \\
Lag 4-2 & $F(96,513)$ & 6.964 & {$[0.000]$} & -6.6992 & -5.5280 \\
Lag 4-1 & $F(128.515)$ & 443.340 & {$[0.000]$} & 8.3618 & 8.9470 \\
\hline Note: Computations from PCGive & 10. AIC = Akaike intormation crito
\end{tabular}

Note: Computations from PCGive 10. AIC = Akaike information criterion and SC: Schwartz criterion. 


\section{Other recent publications in the AERC Research Papers Series:}

Determinants of Private Investment Behaviour in Ghana, by Yaw Asante. Research Paper 100.

An Analysis of the Implementation and Stability of Nigerian Agricultural Policies, 1970-1993. by P. Kassey Garba, Research Paper 101.

Poverty, (irowth and Inequality in Nigeria: A Case Study, by Ben E. Aigbokhan, Research Paper 102.

Effect of Export Earnings Fluctuations on Capital Formation, by Godwin Akpokodje, Research Paper 103.

Nigeria: Tow'ards an Optimal Macroeconomic Management of Public Capital, by Melvin D. Ayogu, Research Paper 104

International Stock Market Linkages in South Africa, by K.R. Jefferis, C.C. Okeahalam and T.T. Matome, Research Paper 105.

An Limpirical Analysis of Interest Rate Spread in Kenya, by Rose W. Ngugi, Research Paper 106.

The Parallel Foreign Exchange Market and Macroeconomic Perfromance in Ethiopia, by Derrese Degefa, Rescach Paper 107.

Market Structure, Liberalization and Performance in the Malawi Banking Industry, by Ephraim W. Chirwa, Research Paper 108

Liberalization of the Foreign Exchange Market in Kenva and the Short-Term Capital Flows Problem, by Njuguna S. Ndung'u, Research Paper 109.

External Aid Inflows and the Real Exchange Rate in Ghana, by Harry A. Sackey, Research Paper 110.

Formal and Informal Intitutions' Lending Policies and Access to Credit by Small-Scale Enterprises in Kenya: An Empirical Assessment, by Rosemary Atieno, Research Paper 111.

Financial Sector Reform, Macroconomic Instability and the Order of Economic Liberalization: The Evidence from Nigeria, by Sylvanus I. Ikhinda and Abayomi A. Alawode, Research Paper 112.

The Second Economy and Tax Yield in Malawi, by C. Chipeta, Research Paper 113.

Promoting Expont Diversification in Cameroon: Toward Which Products? by Lydie T. Bamou, Research Paper 114. Asset Pricing and Information Efficiency of the Ghana Stock Market, by Kofi A. Osei, Research Paper 115. An Fxamination of the Sontres of Economic Growth in Cameroon, by Aloysius Ajab Amin, Research Paper 116.

Trade Liberalization and Technology Acquisition in the Manufacturing Sector: Evidence from Nigeria, by Ayonrinde Folisade, Rescarch Paper 117.

Total Factor Productivity in Kenva: The Links with Trade Policy, by Joseph Onjala, Research Paper 118.

Ke'nya Airways: A Case Study of Privatization, by Samuel Oyieke, Research Paper 119.

Determinants of Agricultural Exports: The Case of Cameroon, by Daniel Gbetnkon and Sunday A. Khan, Rescarch Paper 120.

Macroeconomic Modelling and Economic Policy Making: A Survey of Experiences in Africa, by Charles Soludo, Research Paper 121.

De't'rminumts of Regional Poverty in Uganda, by Francis Okurut. Jonathan Odwee and Asaf Adebua, Research Pitper 122.

Exchange Rate' Policy and the Parallel Market for Foreign Currency in Burund, by Janvier D. Nkurunziza, Research Paper 123.

Siruchural Adjustment, Poierty and Economic Growth: An Analysis for Kenya, by Jane Kabubo-Mariara and Tabithal W. Kiriti, Research Paper 124.

Id beralization and Implicit Govemment Finumces in Sierra Leone, by Victor A.B. Davis, Research Paper 125.

Prreductivity: Market Structure and Trade Liberalization in Nigeria, by Adeola F. Adenikinju and Louis N. Chete, Research Piner 126.

Productivity (ironth in Nigerian Manufacturing and Its Correlation to Trade Policy Regimes/Indexes (19621985), by L ouis N. (hete and Adeola F. Adenikinju. Research Paper 127.

Financial liberalization and Its Implications for the Domestic Financial System: The Case of Uganda, by l.ouis A. Kassekende and Michael Alingi-Ego. Research Paper 128.

Pablic Linterprise Reform in Nigeria: Evidence from the Telecommunications Industry, by Afeikhena Jerome, Research Palper 129.

Food Sc' 'urity and Child Nutrition Status among Urban Poor Households in Uganda: Implications for Poverty Alleviation. by Sarah Nakabo-Sswanyana. Research Paper 130.

Fax Reforms and Re'renue Mobili-ation in Kenya, by Moses Kinyanjui Muriithi and Eliud Dismas Moyi, Research Paper 131.

Hage' Ditermination and the Gender Wage Gap in Kenva: Any Evidence of Gender Discrimination? by Jane Kabubo-Mariara. Research Paper 132.

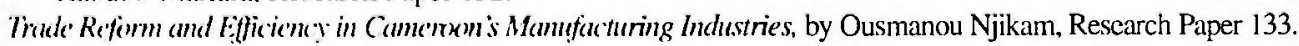


Efficiency of Microenterprises in the Nigeriun Economy. by lghekele A. Ajibefun and Adebiyi G Daramola. Research Paper 134.

The Impact of Foreign Aid on Public Expenditure: The Case' of Ke'ma, by James Njeru. Research Paper 135.

The Effects of Trade Liberalization on Productive Efficiency: Electrical Industry in Cameroon. by Ousmanou Njikam. Research Paper I,36.

How Tied Aid Affects the Cost of Aid-Funded Projects in Ghana, by Barfour Osei, Research Paper 1.37.

Exchange Rate Regimes and Inflation in Tanzamia. by Longinus Rutasitara. Research Palper 138.

Pribate Returns to Higher Education in Nigeria. by O.B.Okuwa. Research Paper 1.39.

Uganda's Equilibrium Real Exchange Rate' and Its Implications for Non-Traditional Exportl' 'erformance. by Michael Atingi-Ego and Rachel Kaggwa Schudde. Research Paper 140.

Dinamic Inter-Links among the Exchange Rate' Price L'vel and Te'ms of Trade in a Managed Floating Exchunge Rate System: The Case of Ghana, by Vijay K. Bhasin. Research Paper 141.

Financial Deepening. Economic Growth and Development: Evidence from Selected Sub-Saharan African Countries, by John E. Ldo Ndebbio. Rescarch Paper 142.

The Determinants of Inflation in South Africa: An Econometric Anulysis, by Oludele A. Akinboade. Franz K. Siebrits and Elizabeth W. Niedermeier, Research Paper 143.

The Cost of Aid Tying to Ghana, by Barfour Osei. Research Paper 144.

A Positive and Normative Analysis of Bamk Supernision in Nigeria, by A. Soyibo, S.O. Alashi and M.K. Ahmad. Research Paper 145.

The Determinants of the Real Exchange Rate in Zambia. by Kombe (). Mungulc, Rescirch Paper 146.

An Evaluation of the Viability of a Single Monetan' Zone in ECOWAS, by Olawale Ogunkola, Researth Paper 147.

Analysis of the Cost of Infrastructure Failures in a Dereloping Economy: The Case of Electricity Sector in Nigeria, by Adeola Adenikinju. Research Paper 148.

Corporate Governance Mechanisms and Firm Financial Performance in Nigeria, by Ahmadu Sandi. Aminu S. Mikailu and Tukur Garba. Research Paper 149.

Female Labour Forre Participation in Ghana: The' Effects of Edtucation, by l Harry A. Sackey, Research Paper 150.

The Integration of Nigeria's Rural and Urban Foodstuffs Marke't, by Rosemary Okoh and P.C. Eghon, Research Paper 151.

Determinants of Technical Efficiency Differentials amongst Small-and Medium-Scale Farmers in Uganda: A Case of Tobacco Growers, by Marios Obwona, Research Paper 152.

Land Conservation in Kenva: The Role of Properț Rights. by Jane Kabubo-Mariara. Researclı Paper 153.

Technical Efficiency Differentials in Rice Production Techmologies in Nigeria, by Olorunfemi Ogundele, and Victor Okoruwa, Research Paper 154.

The Determinants of Health Care Demand in Uganda: The Case Study of Lira District, Northern Uganda, by Jonathan Odwee. Francis Okurut and Asafi Adebua, Research Paper 155.

Incidence and Determinamts of Child Labour in Nigeria: Implications.for Poverty Alleviation, by Benjamin C. Okpukpara and Ngozi Odurukwe. Research Paper 156.

Female Participation in the Labour Market: The Case of the Informal Sector in Kenya, by Rosemary Atieno, Research Paper 157

The Impact of Migrant Remittances on Household Welfare in Ghuma, by Peter Quartey, Research Paper 158.

Food Production in Zambia: The Impact of Selected Structural Adjustments Policies, by Muacinga C.H. Simatele, Research Paper 159.

Poverty, Inequaling and Welfare Effects of Trade Liberalization in Cote dhoire: A Computable General Equilibrium Model Analusis, by Bedia F. Aka, Research Paper 160.

The Distribution of Expenditure Tax Burden before and after Tax Reform: The Case of ' Camerom, by Tabi Atemnkeng Johennes, Atabongawung Joseph Nju and Afeani Azia Theresia, Research P'aper 161.

Macroeconomic and Distributional Consequences of Energy Supply Shocks in Nigeria, by Adeola F. Adenikinju and Niyi Falobi, Research Paper 162.

Analysis of Factors Affecting the Technical Efficiency of Arabica Coffee Producers in Cameroon, by Amadou Nchare, Research Paper 163.

Fiscal Policy and Poverty Alleviation: Some Policy Options for:Nigeria, by Benneth O. Obi, Research Paper 164.

FDI and Economic Growth: Evidence from Nigeria, by Adeolu B. Ayanwale, Research Paper 16.5.

An Econometric Analysis of Capital Flight from Nigeria: A Portfolio Approach, by Akanni Lawanson, Research Paper 166.

Extent and Deteminmantts of Child Labour in Uganda, by Tom Mwebaze, Rescarch Paper 167.

Implications of Rainfall Shocks for Household Income and Consumption in Uganda, by John B. Asiimwe and Paul Mpuga, Research Paper 168. 


\section{AFRICAN ECONOMIC RESEARCH CONSORTIUM}

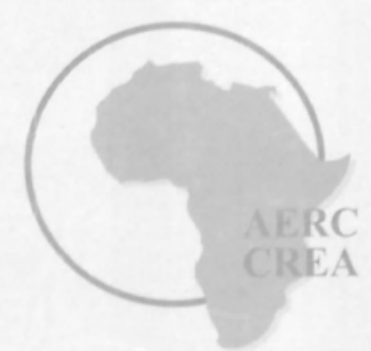

P.O. BOX $62882-00200$ NAIROBI, KENYA

TELEPHONE (254-20) 2734150 273415327341572734163 27341662734179

FAX (254-20) $2734170 \quad 2734173$

E-MAIL:

communications@aercafrica.org

WEB SITE:

http://www.aercafrica.org
$\mathbf{T}$ he principal objective of the African Economic Research Consortium (AERC), established in August 1988, is to strengthen local capacity for conducting independent, rigorous inquiry into problems pertinent to the management of economies in sub-Saharan A frica.

In response to special needs of the region, AERC has adopted a flexible approach to improve the technical skills of local researchers, allow for regional determination of research priorities, strengthen national institutions concerned with economic policy research, and facilitate closer ties between researchers and policy makers.

Since its establishment, AERC has been supported by private foundations, bilateral aid agencies and international organizaitons.

SPECIAL PAPERS contain the findings of commissioned studies in furtherance of AERC's programmes for research, training and capacity building.

RESEARCH PAPERS contain the edited and externally reviewed results of research financed by the AERC.

It is AERC's policy that authors of Special and Research papers are free to use material contained therein in other publications. Views expressed in such papers are those of the authors alone and should not be attributed to the AERC's sponsoring Members, Programme Committee, or Secretariat.

Further information concerning the AERC, and additional copies of Special and Research Papers, can be obtained by writing to: African Economic Research Consortium. P.O. Box 62882 - 00200. Nairobi, Kenya. 
This work is licensed under a

Creative Commons

Attribution - NonCommercial - NoDerivs 3.0 Licence.

To view a copy of the licence please see:

http://creativecommons.org/licenses/by-nc-nd/3.0/ 